UNIVERSITY OF OKLAHOMA

GRADUATE COLLEGE

\title{
AN EXAMINATION OF CAPITAL OUTLAY FUNDING MECHANISMS IN OKLAHOMA
}

\author{
A DISSERTATION \\ SUBMITTED TO THE GRADUATE FACULTY \\ in partial fulfillment of the requirements for the \\ Degree of \\ DOCTOR OF PHILOSOPHY
}

By

CARL JOHNSON

Norman, Oklahoma

2008 


\section{AN EXAMINATION OF CAPITAL OUTLAY FUNDING MECHANISMS IN OKLAHOMA}

A DISSERTATION APPROVED FOR THE

DEPARTMENT OF EDUCATION LEADERSHIP AND POLICY STUDIES

BY

Dr. Jeffrey Maiden, Chair

$\begin{array}{r}\hline \text { Dr. Gregg Garn } \\ \hline \text { Dr. Courtney Vaughn } \\ \hline \text { Dr. Grayson Noley } \\ \hline \text { Dr. Howard Crowson }\end{array}$


(C) Copyright by CARL D. JOHNSON 2008 All Rights Reserved. 


\section{$\underline{\text { Acknowledgements }}$}

As I begin to thank all the people who have helped me on this journey, I can't help but think back to the high school term paper I never finished. Now, as I approach the final period on this last project, I wonder if I can thank everyone who pushed me down this road.

First, I want to thank the families of Robert Eschiti and David Ellis. They may never have any idea that they are a part of this, but Rob and David are never far from my thoughts. I know those guys would appreciate this accomplishment as much as anyone. Their memories are a driving force in my life.

Thank you to the faculty and staff at Jones High School for tolerating the occasional absences and less than cheerful mood that accompanied the deadlines. At least one thing will change.

I owe a great debt to the people I grew up with - my family. My mom, Carla Johnson, thank you for always believing I was perfect. You believed it so much that you convinced me of it. You are the force that holds our family together. Also, thank you Lori for being there for mom. I admire what you represent as a sister, daughter, and most of all a mom. Greg, it is inspiring to know what you have had to overcome. Your perseverance is your greatest strength and something we are all proud of. 
My pursuit of education begins with a role model and often times father figure, Kim Lanier. Uncle Kim has been my professional compass. More importantly he has been my example of how to be a dad. Thank you.

I am truly blessed to have my wife and son. Steph, you have enriched my life through your love and patience. Christopher and I are better men because of you. You stand on the side and allow us to experience a life made better through your hard work. We are witness to your high standard of how to live and live our lives in pursuit of your example. You, Annis, J.W. and the Kinnick clan have given me my greatest honor by accepting me into your family. Thank you all.

My life has been made easy because my son is a good person. As an educator, I have seen children bring out the best and worst in parents.

Christopher, you have always done the former. I am proud beyond my ability to express it. Our number one rule has always been, "Don't embarrass us." You haven't come close. You're talented, passionate, and smarter than I ever hoped to be. I can't imagine how all of that will eventually come together, but I know it will result in a lifetime of success. 


\section{Table of Contents}

Acknowledgements.......................................................

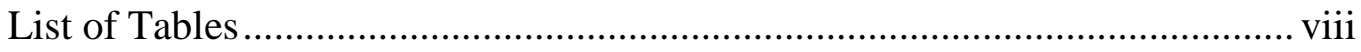

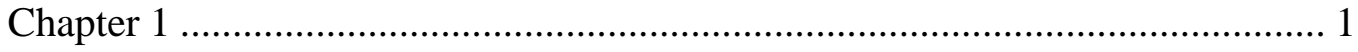

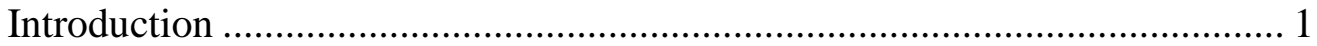

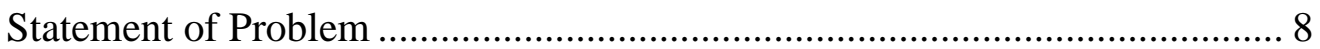

The Problem in Context................................................................................... 9

Why This Problem Continues ................................................................... 14

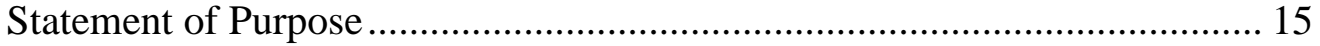

Significance of Study ........................................................................... 17

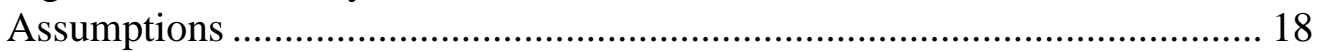

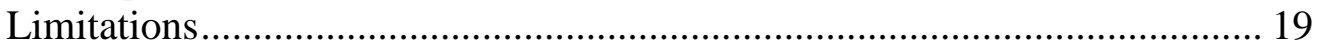

Definitions ............................................................................................ 20

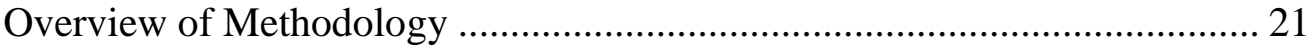

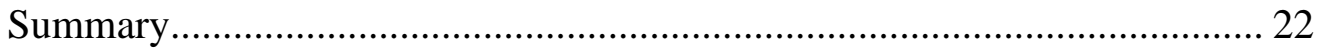

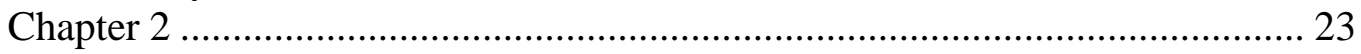

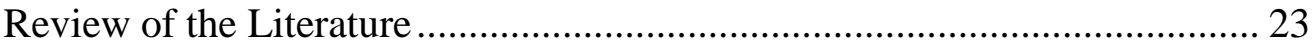

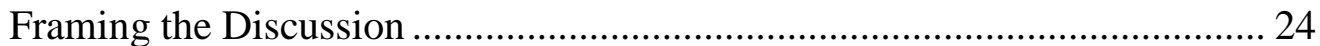

Three Goals of Equity .............................................................................. 28

Wealth Neutrality......................................................................... 28

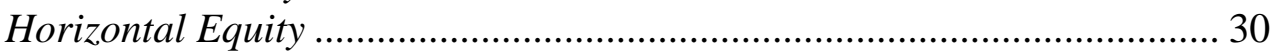

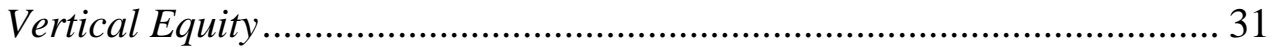

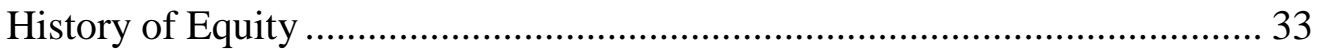

The Courts and Policy .............................................................................. 35

Federal Legislation on Funding School Facilities .................................... 42

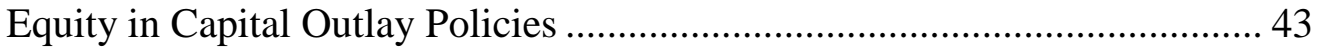

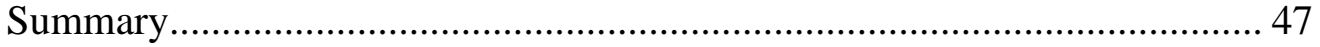

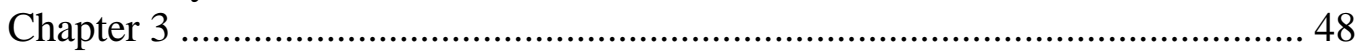

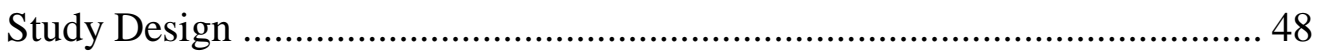

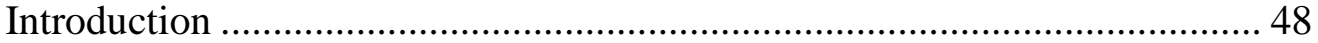

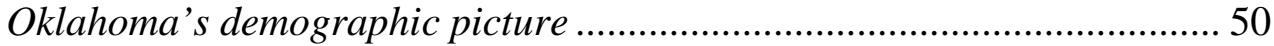

History of Education Reform in Oklahoma ........................................... 52

Oklahoma Department of Education ........................................................ 53

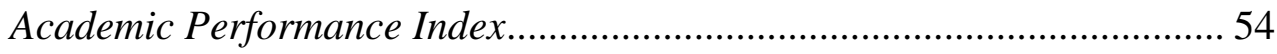

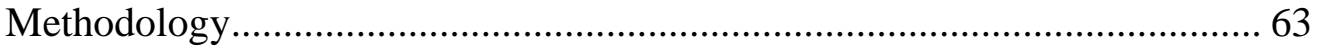




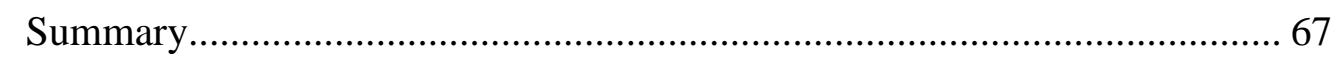

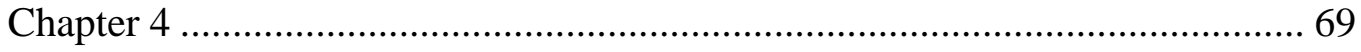

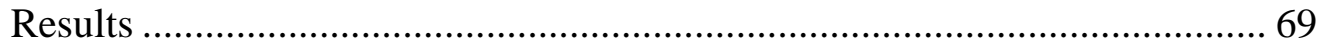

Sample Characteristics .................................................................. 70

Descriptive Statistics ................................................................... 70

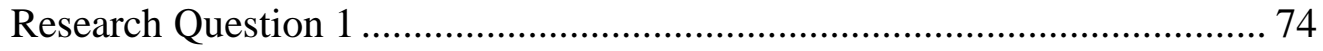

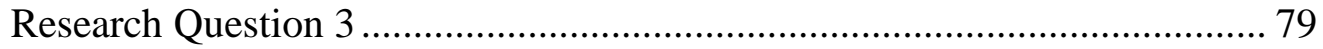

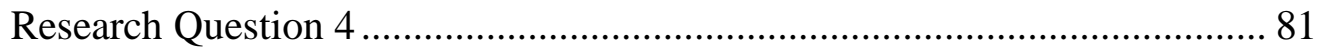

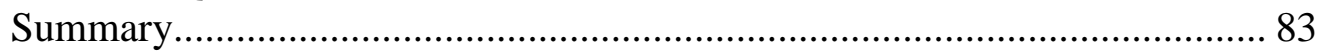

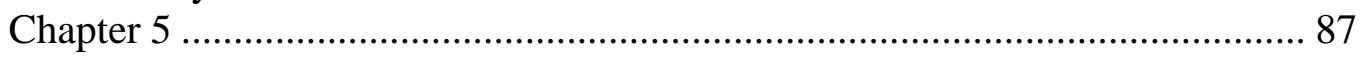

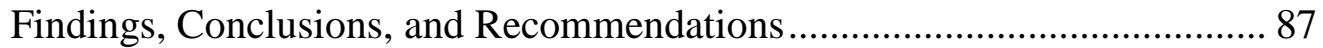

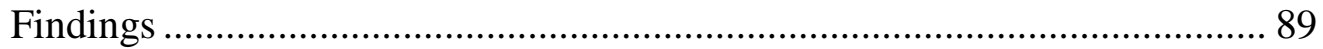

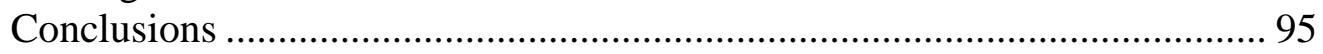

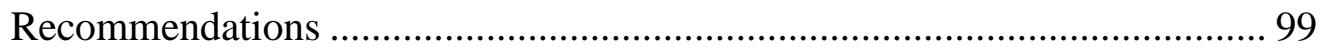

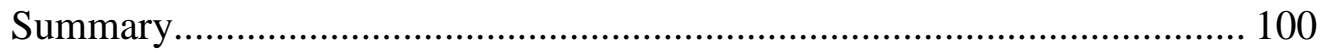




\section{List of Tables}

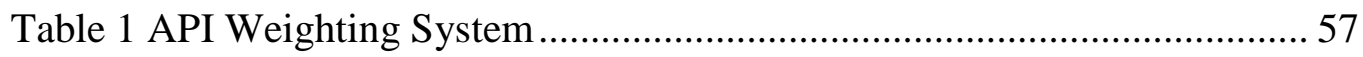

Table 2. Descriptive Statistics for Original Variables ................................... 73

Table 3 Descriptive Statistics for Transformed Variables $(N=540)$................ 74

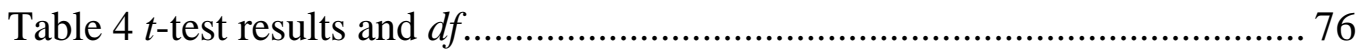

Table $5 t$-test Results Comparing MSA Classifications ….............................. 78

Table 6 Spearman Rank Correlations between SES and Other Variables ......... 79

Table 7 Regression Models for Predicting Capital Outlay Expenditures........... 82

Table 8 Regression Models for Achievement (DISTAPI) .............................. 85 


\begin{abstract}
$\underline{\text { Abstract }}$
The Effects of Capital Outlay Funding Mechanisms on Rural Oklahoma Schools By: Carl D. Johnson Major Professor: Jeffrey Maiden

This is an exploratory study designed to assist in understanding how funding mechanisms in Oklahoma influence school districts in pursuing capital outlay projects, including an emphasis on the differences between rural and nonrural schools. This study also includes an examination of how school performance as determined by the academic performance index is affected by these same mechanisms. The funding mechanisms considered include capital outlay expenditures per pupil, net assessed valuation per pupil, bond issue passage rates, participation in free lunch program, and rurality. Descriptive statistics are presented along with t-tests, correlations, and regressions analysis.

Rural and non-rural were found to be significantly different in net assessed valuation and capital outlay expenditure but not bond passage rate. Socio-economic status was significantly related to and a predictor of capital outlay expenditures. Capital outlay expenditure, net assessed valuation, nor rurality was significantly related to district API scores.
\end{abstract}




\section{Chapter 1}

\section{$\underline{\text { Introduction }}$}

Rural communities may no longer be considered the backbone of this country, but rural schools contribute significantly to the workforce and supply education to one-third of our nation's children. ${ }^{1}$ However, rural schools are often at a disadvantage when trying to fund new facilities because funding availability is based on property taxes. ${ }^{2}$ As a result of urban and suburban policy makers composing the majority of legislatures, the rural voice seldom carries enough weight to bring about meaningful change in their favor. "Rural people are a demographic and political majority in only four states - Maine, Mississippi, Vermont, and West Virginia." ${ }^{4}$ Rural schools face funding issues that metropolitan areas do not. Many of these funding issues deal directly with capital outlay and the inability of rural districts to renovate, remodel, equip, and

\footnotetext{
${ }^{1}$ E. Beeson, \& M. Strange. Why rural matters: The continuing need for every state to take action on rural education. Washington, DC: Rural School and Community Trust. (2003)

${ }^{2}$ R. Gurley, School Capital Funding: Tennessee in a National Context. (2002). Also available at:

http://www.comptroller.state.tn.us/orea/reports/capitaloutlay.pdf

${ }^{3}$ William J.Mathis, Financial Challenges, Adequacy, and Equity in Rural Schools and Communities. Journal of Education Finance. 29 (summer 2003), 119-136.

${ }^{4}$ Ann McColl, \& Gregory C. Malhoit, Rural School Facilities: State Policies that Provide Students with an Environment to Promote Learning. Washington DC: The Rural School and Community Trust. (2004).
} 
build facilities. While there are several studies that suggest students perform better in better facilities, ${ }^{5}$ there is little empirical evidence demonstrating a correlation between student achievement and capital outlay spending. The lack of empirical evidence in support of this connection may result from poor knowledge about school conditions across the country. Few states support a comprehensive, uniform analysis of building conditions. ${ }^{6}$

This study is an attempt to provide a better understanding of the interaction among the various capital outlay funding mechanisms. Conducting this study from a national perspective would be too broad and extensive for this application. Therefore, only one state, Oklahoma, was selected to be the source of data. Eight of Oklahoma's 77 counties are represented by 50 of Oklahoma's 101 house members, and these 50 legislators represent about $50 \%$ of the population. ${ }^{7}$ These legislators and the counties they represent support 540 separate school districts. Fifteen states, including Oklahoma, provide no state funding for buildings. ${ }^{8}$ Eight of these states, again including Oklahoma,

\footnotetext{
${ }^{5}$ Gurley cites Earthman (1996) twice, Bowers, J.H. (1988), Hines, E. (1996), Earthman, G., Cash, C., and Van Berkum, D. (1995).

${ }^{6}$ L, Picus, S, Marion, N. Calvo, \& W. Glenn, Understanding the Relationship Between Student Achievement and the Quality of Educational Facilities: Evidence From Wyoming. Peabody Journal Of Education, 80(3), 72.

${ }^{7}$ Oklahoma House of Representatives 2001 redistricting Plan passed May 2001. http://www.lsb.state.ok.us/

${ }^{8}$ Mary F. Hughes, Financing in Rural School Districts: Variations among the States and the Case of Arkansas. In Improving Rural School Facilities: Design,
} 
measured fiscal capacity using only assessed property valuation. ${ }^{9}$ Oklahoma's rural population, large number of independent school districts, and reliance on property tax for capital outlay funding make it a good model for understanding the relationship of these various mechanisms.

\section{$\underline{\text { Background }}$}

To understand why capital outlay funding has become a critical issue for schools, one must first understand how it relates to equity, student achievement, and tax burdens. It is also necessary to understand the maintenance needs of old buildings including the upgrades in support of technology.

Equity issues took a national stage in the early 1970s. As districts were beginning to come to terms with the forced segregation reforms, equity became an important topic in many public forums and the highest courts. In Serrano v. Priest, ${ }^{10}$ the state of California was held accountable for ensuring that each district had equitable financial means to educate children. However, the efforts were focused on instruction in terms of teacher pay, curriculum, and other items associated with classroom instruction. "While decrepit school facilities played a starring role in many of the lawsuits that impacted state funding systems,

Construction, Finance, and Public Support (pp. 21-39). (ERIC Document Reproduction Service No. ED 445857). (2000).

${ }^{9}$ Hughes, 2000, p. 25.

${ }^{10}$ Serrano v. Priest, 487 P.2d 1241 (1971). 
increased state and federal spending has gone to day-to-day operations, not capital investments." ${ }^{11}$ At the time, there was little attention paid to the effect that the physical learning environment had on student achievement. As a result, it did not come into play in the equity debate.

While state funding for operational expenses has increased dramatically over the last three decades, capital outlay funding has not. ${ }^{12}$ In 1995 , the U.S. General Accounting Office (GAO) conducted a study that has become one of the best sources available when considering school facilities in the U.S. ${ }^{13}$ In that study, the U.S. GAO found that $37 \%$ of rural schools have inadequate science laboratory facilities, $40 \%$ have inadequate space for large group instruction, and $13 \%$ have an inadequate media center. The same report shows rural schools to have significant problems with energy efficiency, air quality, and ventilation.

Not considered until recently is the impact of school facilities on student achievement. If it is true that the condition of a school building has a direct effect on student learning, then capital outlay must be considered an adequacy issue. Some research has been done on this connection, and it is slowly creating a strong picture. In a briefing to the U.S. House of Representatives Committee on Science, Lackney reviewed several studies that showed a positive correlation

${ }^{11}$ Sara Mead. School Construction. Policy Report. Progressive Policy Institute. Washington, DC. (ERIC Document Reproduction Service No. ED 458785). Also available: http://www.pionline.org/ppi_ci.cfm?knlg. (2001).

${ }^{12}$ Education commission for the states 1998.

${ }^{13}$ Mead 2001 
between student behavior and achievement and full-spectrum and natural lighting, the reduction of noise, optimal thermal conditions, the elimination of sick buildings, improved indoor air quality, and school size. ${ }^{14}$ Students whose schools are comfortable and well-maintained are likely to focus more fully on academic challenges than those who are distracted or depressed by the facility in which they spend a large part of their day. ${ }^{15}$ When comparing rural and nonrural schools in Connecticut and Virginia, it was not location but the quality of the schooling conditions that correlated with the higher scores. ${ }^{16}$ As an example, one should not find it difficult to understand how modern science labs contribute positively to science instruction and learning.

By putting the burden of capital outlay on local districts and taxing based solely on property valuation, state legislators in Oklahoma may be placing rural districts at a disadvantage. The low value of farmland, forested and mining areas does not provide sufficient revenue to these districts. There is a strong correlation with number of students per square mile and borrowing power, and borrowing power and percentage of students receiving free or reduced lunches

\footnotetext{
${ }^{14}$ Jeffery A. Lackney, The Relationship between Environmental quality of school Facilities and Student Performance. Energy Smart Schools: Opportunities To Save Money, Save Energy and Improve Student Performance. A Congressional Briefing.

${ }^{15}$ see note 20 above.

${ }^{16}$ Jaekyung Lee. Interstate Variations in Rural Student Achievement and Schooling Conditions. Washington DC (ERIC Document Reproduction Service No. ED 459037). (2001).
} 
are inversely related. ${ }^{17}$ This means that poor and rural school districts do not have the ability to borrow money to pay for new schools even if patrons were willing to tax themselves more. Combine this with general funding based on student enrollment, and small, rural schools are left with tens to maybe just a few hundreds of thousands of dollars to build structures that cost millions. Because maintenance is a discretionary line item, it is often ignored in favor of items more directly related to the classroom. The result is a vicious cycle of the degradation of old buildings and no means of replacing them.

Despite serious obstacles, some states have addressed capital outlay needs in rural schools. Because of court decisions, Arkansas, Texas, Ohio, Colorado and Arizona have recently adjusted their funding formulas to meet the needs of rural schools trying to maintain old facilities. ${ }^{18}$

Many schools built before World War I were intended as centers of community, built with pride to endure and to offer amenities of natural light and architectural grace. ${ }^{19}$ Renovations, however, have not always honored the original greatness of these buildings and, like the original construction taking

\footnotetext{
${ }^{17}$ Hughes, 2000, p.31.

${ }^{18}$ Available http://www.schoolfunding.info/states/ar/lit_ar.php3. National Access Network, Teachers College, Columbia University. John G. Augenblick, 1997, Equity and Adequacy in School Funding. The Future of Children: Financing Schools Vol 7 (3).

${ }^{19}$ Barbara Kent Lawrence, Save a Penny, Lose a School: The Real Cost of Deferred Maintenance. Washington DC: The Rural School and Community Trust. (2003).
} 
place during the middle of the century, were done quickly with inferior materials meant to last approximately 30 years. A lack of sufficient funding for new buildings and deferred maintenance on the old buildings has led to a building crisis for many rural districts.

Many school finance studies deal in some way with the importance and cost of facilities. ${ }^{20}$ Lawrence reports that one out of every two rural schools had at least one inadequate structural or mechanical feature in 1996. In 1999 NCES confirmed that this was true for $52 \%$ of rural schools. ${ }^{21}$ The diseconomy of scale in rural education makes it more difficult for rural schools to maintain, renovate, or build new facilities through the current funding systems. Only Hawaii provides full state funding for capital improvement.

The use of technology in instruction and availability of technology to students are instrumental for a quality school. Because integrating technology into an existing building requires extensive remodeling, technology should be considered concurrent with any discussion of capital outlay funding. The need for technology also increases the need for rural schools to revamp their infrastructure. The availability of technology is a necessary component of rural schools. It will allow better professional development, opportunities to study material and subjects not usually available, and the ability for classroom

${ }^{20}$ See: Lee, 2001, p.1; Lawrence, 2003; Harmon, 2001, p.8; Bingler et. al, 2002, p.6; Hughes, 2000; Lackney, 1997; Thorson and Edmondson, 2002.

${ }^{21}$ National Center of Educational Statistics, 2000, p.2, 14. 
teachers to develop lessons based on constructivist learning theories. Many inner-city urban schools face similar challenges in implementing technology plans. The advantage that most urban and suburban schools have is a long list of local businesses and large corporations willing to invest in those projects. The rural schools seldom have this as an option because these small communities lack a sufficient business base.

\section{$\underline{\text { Statement of Problem }}$}

Many states are facing litigation because school funding formulas are viewed as inequitable. $^{22}$ It is at the state funding level where inequities between metropolitan and rural schools can be reduced. If funding policies at the state level rely on property values to drive revenue, the rural areas and the children that attend school there are at a disadvantage. "The percentage of people living below the poverty level is nearly 30 percent higher in rural areas than in nonrural areas." 23 Rural areas are generally regarded as having a high poverty rate. Over $13 \%$ of the 8.9 million children living in poverty reside in a rural area, and nearly one-third of rural school children live below the poverty level. ${ }^{24}$ Property

\footnotetext{
${ }^{22}$ J.D. McCraken, \& D.D. Peasley. Rural Ohio School Expenditure and student Achievement. Wooster, OH. Ohio Agricultural Research and Development Center. (ERIC Document Reproduction Service No. ED 409128). (1994).

${ }^{23}$ See note 1 above.

${ }^{24}$ Jeffrey Maiden, "Funding School Infrastructure in Rural America". Saving America’s School Infrastructure. 2003. 129-146.
} 
value is also lower in rural areas as farmland, forested areas, and mining areas are worth much less than the dense residential and commercial districts found in urban areas. Rural communities may assess themselves a higher tax rate, and many do, yet still generate fewer tax dollars to invest per student.

As the population in rural areas may not be growing at the rate of metropolitan areas and many times is even declining, it is difficult for many state policy makers to justify reallocating capital outlay to rural districts when a new school may be abandoned in 10 or 20 years. There is an immediate need, however, for the students currently attending school in the property poor districts to receive the same quality instruction as students attending school in property rich districts. The current capital outlay funding practices do not allow local administrators to adequately address facility needs.

\section{The Problem in Context}

This problem is clarified in an example from Oklahoma County. This area in central Oklahoma provides an example of how capital outlay funding mechanisms affect school districts in different ways providing challenges for some and opportunities for others. Within the area of eastern Oklahoma County are four neighboring school districts that face unique challenges and opportunities when addressing facility needs. Oklahoma City Independent 
School district is the largest of the districts, and it is bordered by Oakdale, Jones, and Luther districts.

Oklahoma City school district has taken advantage of a state law that allows the use of sales tax revenues to fund school facilities, which requires only a majority vote to approve. The traditional school bond in Oklahoma requires a super-majority of $60 \%$ voter approval. This is a useful option for districts that see substantial sales revenues. Oklahoma City has been able to renovate and build several new facilities. Several neighboring districts that include some portion of the Oklahoma City corporate limit within their district boundaries have received some funds from the Oklahoma City project. The funds are proportional to the number of students that attend the respective district and live within the Oklahoma City corporate limits.

Oakdale is an elementary independent school district (one that does not support a secondary or high school). Students graduating from $8^{\text {th }}$ grade at Oakdale and still residing in that district may attend any public high school in the state that has sufficient capacity. Most of Oakdale's graduates attend Edmond, another affluent district north of Oklahoma City. In the last 5 years, no more than $5 \%$ of Oakdale graduates have attended Jones even as the Jones High School campus is closer than the nearest Edmond campus. Oakdale has a district enrollment of less than 450, and during the last 10 years, Oakdale has 
spent over \$6 million on capital improvements including classrooms, cafeteria, media center, parking, playground, and a gymnasium.

The Jones school district serves 1100 students with less than $40 \%$ qualifying for free lunches. Capital improvements have been modest with only small additions and cosmetic changes made since 1995.

The Luther school district is similar to Jones school district in size and enrollment; however, $80 \%$ of Luther students qualify for free lunches. Like Jones, the other rural district in this area, Luther has made only modest capital improvements.

Oakdale is able to do more than Jones and Luther because of the capital outlay funding laws in Oklahoma. The Oakdale district has only 9 square miles of transportation area, compared to Jones with 53 square miles. Although much larger in both square miles and student enrollment, Jones is not able to generate the amount of capital improvement revenue that the Oakdale district has available. In Oklahoma, capital outlay funding is based on property values. Each district is valued according to the amount of personal property, public service, and real estate within its boundaries as determined by the county assessor. Within the Oakdale boundaries are some of the most affluent residential communities in Oklahoma County.

The city center of Jones is 10 miles away from any major highway. Except for a few small businesses and 15 churches, which do not create tax 
revenues, there is no commercial development. Compare Oakdale's 2003 total valuation of $\$ 35,815,044$ with that of Jones at $\$ 19,197,789$. Oklahoma also grants a homestead exemption to homeowners who are living in the residence. Businesses and rental property do not receive homestead exemption. Each exemption is $\$ 1000$ regardless of income or square footage. This homestead exemption is then subtracted from the district's total valuation to arrive at the net valuation. Oakdale lost $\$ 401,000$ in homestead exemption in 2003 , while Jones lost $\$ 1,229,000$. Despite serving more children and having less property value, Jones lost more funding through homestead exemption than Oakdale because Jones has more housing (smaller and worth less than housing in the Oakdale district) and less commercial property. The net valuation of Oakdale in 2003 is $\$ 35,414,044$ while the net valuation of Jones is $\$ 17,968,789$. Jones serves 3 times the number of students that Oakdale does and must do so with half the available capital outlay funding. ${ }^{25}$

School Planning \& Management ${ }^{26}$ reports new high schools built in 2003 and falling in the low quartile of schools studied cost an average of \$108.04/Sq.Ft. and used 147.1 Sq.Ft./ Student. Using these figures, it would cost Jones High School $\$ 5,562,439.40$ to build a new facility to replace the

\footnotetext{
${ }^{25}$ Information taken from the Oklahoma County Assessor's web site: http://www.oklahomacounty.org/assessor/Searches/DefaultSearch.asp

${ }^{26}$ Available on the School Planning \& Management web site: http://www.webspm.com
} 
current 60 year old facility. As the last bond proposal would have cost taxpayers $\$ 9.62$ per $\$ 100$ of taxation, this new facility would require taxpayers to tax themselves an additional $\$ 52.91$ per $\$ 100$ of taxation, and $60 \%$ of the voters would need to agree. Even if they did agree, state funding laws do not allow this much. If the district had no bond issues remaining on the books, the most they could request from voters is under $\$ 2,000,000$.

The Luther district has experienced its own unique challenges with the funding mechanisms in place. In Oklahoma, new businesses and businesses conducting significant upgrades are allowed to request a 5-year tax exemption. This law is intended to encourage economic growth in the state. Five years ago, Luther would have appeared to be more in line with Jones with respect to net valuation. Since that time, a $\$ 70,000,000$ power plant has come on line inside district boundaries; however, by using the tax exemption laws, the plant will pay no ad valorem tax for five years. The state legislature is obligated to refund to the schools any lost revenue. This new valuation within the district has given local educational leaders a much larger revenue base with which to build new facilities. This amount of net assessed valuation is more than enough to provide the needed resources cited earlier to build any necessary facilities.

This example of districts in eastern Oklahoma County demonstrates how capital outlay funding mechanisms affect schools in different ways. All four districts have unique challenges and revenue opportunities. Some realize much 
greater per pupil revenue from these resources. The effect of the differing capital outlay expenditures of these districts on student achievement does not provide such a neat example.

\section{Why This Problem Continues}

Understanding the relationship between student achievement and capital outlay funding is difficult. The first obstacle is quantifying building condition and needs. Assessing independent features of a building across all subjects within a study creates a uniformity problem. Assessing these conditions is subjective and would require a small group of evaluators to inspect each facility. The maintenance history of buildings makes using the age of the structure as a variable impossible.

The second obstacle is a poor understanding of the complex relationship among demographics, school district location, state funding policies, and local decision making processes. The process of using available capital outlay funds is subject to local values, experience, and assessments. Local needs assessments may identify future projects that fall outside the realm of student academic assessments. A local school board may decide to build a gymnasium, agriculture facility, or vocational technology center. These projects would have little impact on common academic assessments focusing on reading and math, yet are important in the operation of a district. 
When the funding mechanisms that drive capital outlay revenue in one state can have such varied effects on districts in the same county, it is important to understand if equity is being maintained state wide. Districts that struggle to find capital outlay revenue often use the funds that are available to maintain only the most needed areas. While communities look to provide safe schools and clean buildings, it is not unimaginable to expect that the students in the most rural areas of Oklahoma and other states have the same opportunities in the arts as students in districts with high property value. These children are just as deserving of modern auditoriums in which to perform and present their talents as students in the wealthiest suburb. A student's opportunities to achieve, explore, and grow as an American citizen should not be limited by how far their house is from a major highway or if an energy plant is built in the district.

\section{Statement of Purpose}

Because of a lack of theory in the area of capital outlay funding in public schools, the intent of this study was to explore the basic mechanisms involved in capital outlay funding for public schools and provide guidance for further research and variable selection. While this study was not designed to suggest new theory or test current theory, it did examine Oklahoma's current capital outlay funding mechanisms to determine if districts differ in their ability to support facility needs. Because this is an exploratory study, it included research 
questions rather than hypotheses. While this is not a pure equity study, equity was considered throughout. Oklahoma's capital outlay funding was considered from a variety of mechanisms including assessed valuation, ability to pass bond elections, and expenditures. Each was analyzed through comparisons of rural and non-rural and socio-economic status. Also, this study analyzed how assessed valuation, SES, and rurality affect capital outlay expenditures.

\section{$\underline{\text { Research Questions }}$}

This study is guided by the following research questions:

1. Is there a statistically significant difference in each of the following indicators of district capacity to meet capital outlay needs among Oklahoma districts according to Metropolitan Statistical Area classification?
a. Bonding capacity
b. Bond passage rates
c. Per pupil capital outlay expenditures
d. Net assessed valuation per pupil

2. Is there a statistically significant relationship between district socioeconomic status and the following indicators of local district ability to meet capital outlay needs in Oklahoma?

a. Bonding capacity 
b. Bond passage rates

c. Per pupil capital outlay expenditures

d. Net assessed valuation per pupil

3. What is the predictive power of each of the following district characteristics on capital outlay expenditures per pupil in Oklahoma?
a. Bonding capacity
b. Bond passage rates
c. MSA designation
d. District SES

4. Is there a statistically significant relationship between each of the following district characteristics and achievement among Oklahoma school districts?
a. Bonding capacity
b. Bond passage rates
c. MSA designation
d. District SES
e. Capital outlay expenditures per pupil

\section{$\underline{\text { Significance of Study }}$}

Prior to analyzing the adequacy of Oklahoma's school funding policy, it is important to understand how specific parts of that policy affect each district's 
ability to operate. It is also important to understand the complex relationship capital outlay funding has with other factors in public school finance. By analyzing how capital outlay functions are affected by each district's demographic characteristics, this study will contribute to a larger body of knowledge that may attempt to determine the adequacy of the Oklahoma school funding system. This study provided a more accurate determination of equity within the system. Other studies have examined equity by analyzing total spending for rural and non-rural schools. The analysis presented in this study will determine if more specific factors affect spending by including two levels of rurality as defined by the U.S. Census Bureau, SES, current expenditures, local wealth, and local support as variables. This study will identify how these capital outlay funding mechanisms in Oklahoma are related to one another and the effect they have as a group and individually on the ability of local educational leaders to address facility needs. State level policy makers will be able to use this data in consideration of changes to funding policy.

\section{$\underline{\text { Assumptions }}$}

It is assumed that the percentage of students receiving free or reduced price lunches is a sufficient determination of socio economic status. This is an often used data source with a high degree of validity within the industry; however, Coladarci reports that the negative effect of SES tends to be lower 
among smaller schools, and he suggests caution when using it to study student achievement in small and rural schools. ${ }^{27}$ The use of SES as a variable in this study captures financial and taxing ability not student achievement.

\section{$\underline{\text { Limitations }}$}

This study uses the Oklahoma Cost Accounting System (OCAS) as the data source for expenditures. While the use of this system is regulated and strictly enforced by the state of Oklahoma, district administrators may interpret coding categories differently. This will cause some limitation to the study. The data on capital outlay does not include grants, donations, or expenditures by outside agencies that are not included in the OCAS reporting. This study has little predictive value and should be used only to better understand the complex relationships among capital outlay funding, district level demographics, and Oklahoma public school finance.

This study does not account for funding sources outside of typical education general obligation bonds that are association with special school bond elections. Lease purchase revenue bonds (discussed later) are a relatively new funding process in Oklahoma, and data identifying that source are not

\footnotetext{
${ }^{27}$ T. Coladarci, "School size, student achievement, and the "power rating" of poverty: Substantive finding or statistical artifact?". Education Policy Analysis Archives, 14(28). (2006). http://epaa.asu.edu/epaa/v14n28/.
} 
maintained at the state level. Other funding sources may also include grants, gifts, and donations.

\section{$\underline{\text { Definitions }}$}

Capital outlay is defined as expenditures that result in the acquisition of or addition to fixed assets such as land, buildings, and equipment. ${ }^{28}$

The United States Census Bureau uses micropolitan statistical area, metropolitan statistical area, and rural as defined by the Office of Management and Budget effective June 6, 2003. ${ }^{29}$ Metropolitan Statistical Area.-A Core Based Statistical Area associated with at least one urbanized area that has a population of at least 50,000. The Metropolitan Statistical Area comprises the central county or counties containing the core, plus adjacent outlying counties having a high degree of social and economic integration with the central county as measured through commuting. Micropolitan Statistical Area.-A Core Based Statistical Area associated with at least one urban cluster that has a population of at least 10,000, but less than 50,000. The Micropolitan Statistical Area comprises the central county or counties containing the core, plus adjacent

\footnotetext{
${ }^{28}$ Hughes, "Financing Facilities in Rural School Districts: Variations among the States and the Case of Arkansas"

${ }^{29}$ United States Census Bureau. "About Metropolitan and Micropolitan Statistical Areas." http://www.census.gov/population/www/estimates/aboutmetro.html.
} 
outlying counties having a high degree of social and economic integration with the central county as measured through commuting. ${ }^{30}$

\section{Overview of Methodology}

The Oklahoma Cost Accounting System was used to collect data from 540 school districts, and all 77 county election boards were contacted with a request for voting data. Responses were high (90.9\%) with 70 of the 77 counties responding with complete data. From these data, descriptive statistics were created including means, maximums, minimums, standard deviations, skewness, and kurtosis. Research question 1 was addressed through 3 separate t-tests for each of the five years of data. Rural and non-rural was used as the grouping variables while bond approval rate, capital outlay expenditure (COE), and net assessed valuation (NAV) were used as independent variables. Research question 2 used a Spearman rank correlation with socio-economic status, bond passage rates, COE, and NAV as the variables. Research question 3 was addressed by computing a multiple regression in which $\mathrm{COE}$ was regressed simultaneously on the variables NAV, bond passage rates, rural / non-rural, and socio-economic status. Research question 4 also used a multiple regression;

\footnotetext{
${ }^{30}$ Federal Register. Vol. 65(249). Wednesday, December 27, 2000. Notices http://www.whitehouse.gov/omb/fedreg/metroareas122700.pdf
} 
however, district academic performance index scores were regressed on NAV, bond passage rates, rural / non-rural, socio-economic status, and COE.

\section{$\underline{\text { Summary }}$}

Determining the adequacy of a state's public school finance system is a difficult task. Understanding how the various components of a system serve the intended purpose is a necessary first step, and capital outlay funding is a critical component of the state system. Some districts are able to construct new facilities will little difficulty or opposition, but many (mostly small, rural districts) are not able to generate enough bonding capacity to fund projects beyond cosmetic or general repairs. Many children are attending school in buildings that would have been replaced long ago if they were used in other industries; however, it is beyond the ability of many rural communities to address their facility needs without help from the state. This study will provide a general understanding of how the funding mechanisms in Oklahoma are affected by rurality, SES, local wealth, and local support of building projects. 


\section{Chapter 2}

\section{$\underline{\text { Review of the Literature }}$}

"Major disparities" in educational opportunities were reported after a review of aggregated national statistics during the middle of the $20^{\text {th }}$ century. The cause of these disparities went beyond race, gender, and mental and physical handicaps - commonly known sources of inequality. The disparities in the educational system were also the result of "differences in place of residence, family occupation, and income." ${ }^{31}$ The debate over equity in public education arrived on the front page in the early 1970s with the California Supreme Court decision in Serrano V. Priest. ${ }^{32}$ It has continued over the last three decades reflecting the political and social climate of the time. A review of education finance literature shows two distinct constructs determining how schools should be financed. This chapter discusses how equity concepts drive education funding. The chapter begins by framing the discussion because it is important for the reader to understand what equity is and how it is defined by the education community. The sections that follow include discussions of the three

\footnotetext{
${ }^{31}$ Reported by H.F. Ladd and J.S. Hansen eds. Making money matter: Financing America's schools (Washington D.C.: National Academy Press 1999). Here they were referencing D. Tyack and L. Cuban. Tinkering toward utopia: A century of public school reform. (1995). Cambridge, MA: Harvard University Press.

${ }^{32}$ Serrano v. Priest, 487 P.2d 1241 (1971).
} 
goals of equity, a history of equity in education, education funding in the courts and public policy, and equity in capital outlay.

\section{Framing the Discussion}

By raising the debate on equality, the civil rights movement became a contributor to the public school finance argument. As society became familiar with equality issues, education reformers began to articulate the need for equity within the public school structure.

Equity should not be confused with equality. Equality is the mantra of people that are persecuted against because of race, gender, religious affiliation, or national origin. Equality is associated with social goals. Equity, especially in the public education arena, means much more. Equity demands that we provide to those who have less the resources to accomplish the same goals as those who have more. "An equitable system of education is one that offsets those accidents of birth that would otherwise keep some children from having an opportunity to function fully in the economic and political life of the community."33 Following the publication of $A$ Nation at Risk ${ }^{34}$ there was a nationwide call for increased performance in our public schools. It was believed that American school

${ }^{33}$ H.F Ladd, R. Chalk, and J.S. Hansen eds. Equity and adequacy in education finance (Washington D.C.: National Academy Press 1999).

${ }^{34}$ A Nation at Risk; The Imperative for Educational Reform. A Report to the Nation and the Secretary of Education United States Department of Education. The National Commission on Excellence in Education. 1983. 
children were not as capable as children in the rest of the world. Americans became more interested in what school children could do. Like the civil rights movement two decades earlier, this political movement resulted in the second education finance construct. Similar to equity on the surface, adequacy differs because it is anchored to the standards based schooling movement. While equity focuses on opportunity and inputs, adequacy focuses on achievement and processes. Inputs include teacher salaries, classrooms, books, equipment, and anything needed to conduct school. Processes refer primarily to pedagogical techniques. Financial adequacy in education means providing children with the resources they need to meet minimum criteria.

This review of the literature will focus on the relation of equity to public school policy and how the evolution of equity to adequacy has affected policy. First, it is necessary to distinguish how equity is to be understood in this discussion followed by a presentation of the three goals of equity in education. There are five key elements that will frame the understanding of educational equity in this study. These distinctions are taken from the work of Berne and Stiefel $^{35}$ and are presented in the following sections.

Determining the focus of concern targets the core aspect of the discussion. When considering these ideas of finance, one must first recognize which taxing perspective is most appropriate to the issue. Because equity is

${ }^{35}$ Referenced by Ladd \& Hansen. 
associated with opportunity, the child is often the primary concern; however, by using public funds to support the system, the taxpayer becomes an important and fair consideration. ${ }^{36}$ The capitalization of state aid is an important aspect of school finance that focuses on the taxpayer. Capitalization refers to the change in property values that often accompany changes in school finance policy. It is sometimes difficult to understand how dollars delivered to schools through the foundation formula do not always contribute to the intended program at the same level that was originally intended. State aid dollars are sometimes used to lessen the tax burden in a community. The dynamic relationship among these factors is complex and will affect property values in the end. This is known as capitalization. ${ }^{37}$ Unless otherwise noted, the perspective here will be the child.

What is the unit of analysis? Wealth neutrality, horizontal equity, vertical equity, and adequacy each provide a distinct model that researchers and policy-makers may use to understand school funding. These models may be applied at the federal, state, district, school, and student level. The discussion here will apply primarily to the national and state level arguments; however, when discussing adequacy, the district and school will be considered as units of analysis. Students are of course always the primary concern of any discussion

\footnotetext{
${ }^{36}$ Ladd, Chalk, \& Hansen p.10.

${ }^{37}$ P.G. Wyckoff, Capitalization and the Incidence of School Aid,: Journal of Education Finance 27 (Summer 2001): 585-608..
} 
of education; however, the topics presented here are too broad in scope and perspective to provide relevant application at the student level.

Which stage in the "production" of education is emphasized? Here again, each of concepts of equity provides unique problems and insights when considering the various stages. Inputs, processes, and outputs will each be considered during some portion of this discussion. Equity is most easily applied to inputs. Processes and outputs, that is pedagogy and achievement, will be considered during the discussion of adequacy. Outcomes are often considered as a fourth stage of this paradigm; however, little research could be found in this area. Outcomes refer to the long-term effects of an education - income, life accomplishments, and health. Because of the broad nature of this idea and lack of literature, it is not discussed here.

Which groups are of special interest? Specific studies will focus on a single or a few groups, but as this review is a broad discussion of equity, all groups are considered. The only distinction is for public K-12 education as compared to private, parochial, home school, or post-secondary education.

How is the equity of the school finance system being evaluated? The two options here are ex ante and ex post. Ex ante refers to how the finance formula is written and put together. Ex ante evaluations seldom consider what happens in the classroom or even at the district level. Ex post evaluations are conducted with output data. The research that was analyzed for this review used 
both options; however, some of the studies contributing to the discussion of policy were conducted through an ex ante lens but with ex post type data without considering how local decisions might affect state level policy. This is discussed later.

For the purposes of this literature review, children are the primary concern but seldom the unit of analysis. This review will consider inputs, processes, and outputs as they apply to specific goals of equity. It will not consider outcomes. No specific group within the $\mathrm{K}-12$ public education arena is given special consideration. School finance will be discussed in terms of national and state level policy and how it is applied to affect outcomes.

\section{Three Goals of Equity}

State level judicial and legislative debates over education finance begin with the idea of equity. From these debates, equity has surrendered three defining goals: wealth neutrality, horizontal equity, and vertical equity.

\section{Wealth Neutrality}

The concept of wealth neutrality is the result of a finance system based on property taxes. It was at the core of the Serrano case in $1971 .^{38}$ At the most basic level, wealth neutrality means that the education of a child will not be

${ }^{38}$ Although articulated through this case, the principle was first introduced by Coons, Clune, and Sugarman in Private Wealth and Public Education (Cambridge, MA; Harvard University Press, 1970). 
determined by property wealth around the school; therefore, only the wealth of the state as a single entity should determine what kind of resources are available for a child's education. To achieve wealth neutrality, some states implemented a guaranteed tax base (GTB) or district power equalizing (DPE) formula. ${ }^{39}$ However, these formulas proved to not equalize spending or eliminate the nexus between wealth and spending. The problem with these formulas is, because they provide only minimal funding, schools must continue to rely on local effort and fairness. Only two states continue to use flat grants - Delaware and North Carolina. ${ }^{40}$ The answer for many states now is a foundation formula. By attempting to create a system of balance between local and state funding, a foundation formula sets a per-pupil minimum below which state funding shall not fall. By 1998-99, 44 states used this type of funding mechanism. ${ }^{41}$

Oklahoma uses a foundation aid formula with a transportation supplement and modified guaranteed yield as a second tier of funding. In the Oklahoma formula, the state legislature begins by appropriating state aid for the two-tiered equalization formula. Local effort is achieved through five mechanisms. Ad valorem, school land earnings, gross production tax, motor vehicle tax, and rural electrification association taxes at the local level are

\footnotetext{
${ }^{39}$ M.G., Addonizio, "From Fiscal Equity to Educational Adequacy: Lessons from Michigan," Journal of Education Finance 28 (Spring 2003), 457-484.

${ }^{40}$ See note 3 above.

${ }^{41}$ See note 8 above.
} 
"charged" against a base state aid so as to equalize per pupil spending at the local level. The inverse relationship is intended to balance state funding with local funding. The idea is that every district will have the same overall funding per pupil.

The two-tier system also uses a modified guaranteed yield formula to create a salary incentive aid component. A district's highest weighted average daily membership (ADM) from the previous two years (to include the current first quarter) is multiplied by an incentive aid factor. The district's adjusted assessed valuation (short any protested ad valorem) is divided by 1000 and subtracted from the product of the ADM and incentive aid factor. The remainder is multiplied by any general fund mills above 15 (not including county 4 mill levy). ${ }^{42}$

Through this formula, Oklahoma is making an attempt at wealth neutrality. It is measured at the state or district level without regard to subgroups. By looking at equity within certain groups, one is then considering horizontal equity.

\section{Horizontal Equity}

The goal of horizontal equity is to ensure that children in similar situations are educated with equal funding. The burden for the researcher and

\footnotetext{
${ }^{42}$ Oklahoma Statute 70-18-200.1, Section 422.1, State Aid, Foundation Aid, Transportation Supplement, Salary Incentive Aid.
} 
policy maker is to recognize and defend the selection of similar situations. There are some groups that have easily recognizable boundaries; economically disadvantaged, English as a second language, and special education children are often in such groups. Grade levels are also used to determine horizontal equity. Horizontal equity is a lens through which one would look across similar groups and then determine if members of the groups are receiving equal treatment. Unlike wealth neutrality, horizontal equity is a concept that is easily applied at the local level. The idea of horizontal equity as a research interest is usually applied to resources available for inputs. That is resources that go into the application of education. It is limited as an application when considering outputs.

\section{Vertical Equity}

Because the intention of the system should be to eliminate the effects of the circumstances that created the distinctions between the groups, policy makers must consider vertical equity when developing funding policy. Vertical equity implies that unequal groups are treated unequally. Because compulsory attendance laws often excluded children with disabilities, these children represented less than 1 percent of all 
children served in $1938 .{ }^{43}$ Those same groups that the researcher was concerned with as having internal commonality in horizontal equity issues are looked at in inter-group comparisons to determine that those in need of increased resources receive just that. Most researchers agree that increased resources are needed for some groups; however, how much to increase these resources is debated. Most formulas address vertical equity through weighted student counts. Students in certain groups are counted as "more than one." Perhaps a student identified as economically disadvantaged is given an additional .25 when counted so as to add 1.25 to the overall student count. The problem here is that the weights are ad hoc with little or no connection to the needs of these groups. Vertical equity is closely associated with the Coleman report. ${ }^{44}$ Schools must find a way to account for those external factors that affect student performance. How schools are able to account for and manage those factors begins with funding, and that process begins with legislators creating policy.

\footnotetext{
${ }^{43}$ Ladd \& Hansen (68).

${ }^{44}$ J.S., Colemen, et al., Equality of Educational Opportunity (Washington D.C.: Office of Education, 1966). This work showed that student performance was dependant more on environmental factors including socio-economic levels than what the school was doing. This was a dynamic effect influenced as well by the other students in the school and their unique environmental situations.
} 


\section{History of Equity}

One of the first obstacles facing Horace Mann and other proponents of common schools was finding funding for opening new schools. States used land grants, attendance incentives, and other state mandates to force local communities to open schools. These beginning endeavors also included distribution formulas and state financial incentives to expand local educational offerings. School finance experts became major players in policy formation in the late 1960's when equity became the bell cow of school reform. The equity era was focused on managing resources for inputs as equally as possible. Researchers and lawyers convinced judges that students had a right under the fourteenth amendment to receive equitable funding regardless of wealth, locale, or circumstances. The early 1970's were watershed years for these reformers with the Serrano case in California serving as the banner.

The United States Supreme Court quickly defined the boundaries of the debate when in 1973 it refused to rule in San Antonio v.

Rodriquez. ${ }^{45}$ This was a Texas case modeled after the Serrano argument; however, by refusing to rule, the United States Supreme Court limited the debate to the state level. This event had the affect of creating 50 different educational finance systems. Each is unique in funding

${ }^{45}$ San Antonio Independent School Dis. v. Rodriguez, 411 U.S. 1 (1973) 
mechanisms and effectiveness. Education finance researchers and reformers active in the equity debate were forced to analyze each system. These are systems different in design but similar in complexity. Each system is also influenced by well-established regional biases and belief systems. Since the Rodriquez decision, nearly every state has experienced a challenge to its school finance formula. These challenges have been only occasionally successful in the courts, but they have influenced policy nonetheless.

In a review of school finance litigation literature, Thompson and Crampton ${ }^{46}$ found that, "most studies do not show a clear trend of improved equity, regardless of whether a lawsuit was won, lost, or even filed. Second, the majority of studies suggest that nearly as much change in formula design may result from voluntary legislative reform as from court-ordered reform. In sum, a majority of studies suggests only that school finance has received heightened scrutiny as a result of litigation and that such force may have had a positive effect that might not have occurred had the pressure not been present."47 The debate over equity

\footnotetext{
${ }^{46}$ D.C Thompson, , and F.E. Crampton, "The Impact of School Finance Litigation: A Long View,” Journal of Education Finance 27 (2002), 133-173. ${ }^{47}$ ibid
} 
marks the beginning of modern school finance. When equity was argued in court, finance policy began to change.

\section{The Courts and Policy}

After an understanding of equity and adequacy, one must begin to recognize how these two constructs affect policy. The short answer is through the courts. Many states have been forced to change their school finance system by the courts. Others have changed to keep out of the courts. Either way the equity or adequacy question is always the driving force behind change. It is through an analysis of judicial proceedings that one may understand the nexus between equity and policy.

While Serrano I was the first successful attempt to change school finance policy through the courts, it was not the first attempt. Focusing of the U.S. Constitution's Fourteenth Amendment provision, early reformers developed ideas that evolved into current understandings of horizontal and vertical equity. Unfortunately, courts at the time found it too difficult to manage standards based on student's needs. The early idea of "one scholar, one dollar" was based on wealth neutrality, but it does not provide districts with the opportunity to increase local effort. This was a political obstacle as it is in conflict with parents (communities) right to provide for their children in a manner they 
beleive is appropriate. Local districts would be limited to what they could tax themselves in support of education. Any dollar raised in district "A" would have to be delivered by the state to district "B." This becomes cost prohibitive.

A similar principle was developed that might allow for districtto-district differences. Geographic uniformity differed from one scholar, one dollar by allowing districts to adjust spending based on sub-group needs. Geographic uniformity is an attempt at vertical equity. This principal, however, still did not provide enough room for local effort, and more important to legal aid lawyers, it did not mandate additional spending for at-risk students. Reformers attempting to reconcile the two principles developed the idea of unequal student need. It is this third concept of equity that was the first to be argued in federal court. It was in Illinois and Virginia that the district courts ruled against claimants' based on judicially unmanageable concepts. ${ }^{48}$

Reformers were finally successful at the state level with their arguments in Serrano. The arguments this time were based on the work

${ }^{48}$ As per Ladd \& Hansen: see McInnis v. Shapiro, 293 F. Supp. 327 (N.C. Il. 1968), aff'd sub nom., McInnis v. Ogilvie, 349 U.S. 322 (1969); Burrus v. Wilkerson, 310 F. Supp.572 (W.D. Va. 1969), aff'd per curiam, 397 U.S. 44 (1970). 
of Coons, Clune, and Sugarman. ${ }^{49}$ The concepts represented in this work and argued in California State Supreme Court would become understood as wealth neutrality. The key to this argument was the connection between property tax and per-pupil funding. Poorer districts had less property to tax, so even if the local effort was greater than a more property rich district, the net result was less per-pupil spending. Wealth neutrality is a measurement of taxing sources not student needs. This distinction provided the courts with a measurable goal.

After the Serrano decision, the California legislature made minor adjustments to its school funding policy. These adjustments, however, did not eliminate local wealth as the primary determiner of per-pupil expenditures. The result was a second Serrano case. In 1976 the court ordered the California legislature to try again. This time the court offered a list of acceptable plans. Among these was the Coon's district power equalization plan. Also important to this case was the court's assertion that the previous decision was applicable to the California constitution. After the first case, it was assumed that the primary application of the ruling was to the United States constitution's fourteenth amendment. As the United States Supreme Court had ruled

${ }^{49}$ Coons, J.E., William Clune, Sugarman, S.D. Private Wealth and Public Education. (Cambridge: Belknap Press, 1970). 
that there was not application to the United States constitution, the California court had to justify their decision by making clear their intent and aligning it with the state constitution. Before the Serrano $\mathrm{II}^{50}$ ruling could be put into effect, the voters of California adopted Proposition 13. Proposition 13 limited property tax rates to $1 \%$ of the cash value of real property subject to taxation, required two-thirds vote of the legislature to increase state taxes, and prohibited the imposition of a statewide property tax..$^{51}$

Because the Serrano II decision had also required that per-pupil expenditures differ by no more than $\$ 100$ (in 1971 dollars) not counting categorical aids, the California legislature was left to devise a system that relied heavily on state revenues to eliminate disparities. The net effect has been that California, once having one of the highest public school budgets, is now below the national average in public education expenditures. Despite what seem to be obvious cause and effects among the Serrano decisions, Proposition 13 and the decline of education expenditures in California, research has not shown any clear connection.

\footnotetext{
${ }^{50}$ Serrano v. Priest II 557 P.2d 929 (Cal. 1976).

${ }^{51}$ P.A. Minorini, and S.D. Sugarman, "School Finance litigation in the Name of Educational Equity" Equity and Adequacy in Education Finance: Issues and Perspectives, Helen F. Ladd, Rosemary Chalk, and Janet S. Hansen, eds. Washington, DC: National Academy Press (1999) 49.
} 
Following the success of the California ruling, education finance reform advocates were disappointed when the United States Supreme Court overturned a lower federal court decision in Rodriquez. The argument originally accepted by the lower court was based on the same Coons team's theory of wealth neutrality and the reliance on property taxes to fund the system. The United States Supreme Court dismissed the claim that district wealth is a "suspect classification" for determining the amount of education funding a student receives. Education had been accepted as a "fundamental interest" within the Texas constitution. When a fundamental interest is violated, it is subjected to a test of "strict judicial scrutiny." A "compelling state interest" is required to justify this violation. $^{52}$

The argument was made that wealth was being used as a classification with which to restrict a student's right to an education. When the United States Supreme Court ruled that education was not a fundamental interest it lessened the requirement for the state to show only a "rational basis" for the system. With the United States Supreme Court dismissing the notion that the fourteenth amendment was a basis for determining equity, the focus turned to individual state constitutions. The reform advocates again gained ground in New Jersey.

${ }^{52}$ Ladd \& Hansen (77). 
Perhaps second only to the Serrano cases in California, the judicial proceedings in New Jersey demonstrate more than any other the impact that equity issues have on policy. Shortly after Serrano, the New Jersey Supreme Court heard arguments in Robinson v. Cahill, 303 A.2d 273, 1973 (Robinson I). The arguments and outcome were similar to Serrano. The New Jersey court, however, based its ruling only on the New Jersey constitution; there was no reliance on the United States constitution. The New Jersey constitution contains the clause, "thorough and efficient system." This subjective phrase provided enough ambiguity to keep the issue in the courts for the next 25 years. By grounding the decision on this language, the court did something that has had national impact. It gave reformers alternative grounds on which to base equity arguments. State constitution education clause wording has come under close scrutiny and the basis for declaring funding policies unconstitutional. When the New Jersey courts reviewed the new funding policy, it was found to be in compliance. The courts also found that the legislature had adopted statewide standards and ordered that student achievement toward those standards be monitored. This introduced a new discussion into the debate. The court's decision included, in fact centered on, the ability of the new funding mechanisms to accommodate the new standards requirement. For the first time, educational 
opportunities overtook traditional considerations of wealth neutrality as the vehicle for equity. This idea evolved further into what is discussed today as adequacy. In a unique reversal of policy formation, the New Jersey Supreme Court took plans offered by the State Commissioner of Education and implemented them into the most recent ruling. This has now created a law to which the state legislature must abide.

As one of the stated purposes of this review is to demonstrate the effects of equity on policy, it does not make sense to analyze the many court cases that ruled in favor of the defendant or current policy. It is important, however, to understanding the concept of equity to consider some of the arguments against the Coons team's theories. Some decisions against reformers centered on the court's reluctance to legislate and possibly violate the separation of powers standard. Other courts continued to doubt the suggested positive correlation between funding and student achievement. The Oregon Supreme Court feared that by agreeing that the lack of funding equated to an equal protection violation they would invite similar arguments for other civil services including police and fire departments. ${ }^{53}$

${ }^{53}$ Olsen v. State, 554 P.2d 139 


\section{Federal Legislation on Funding School Facilities}

In 2000 , the country began to see efforts being made at the national level to provide relief for school construction funding.

Not surprisingly, a typical partisan breakdown has characterized school construction since President Clinton first proposed a large-scale plan to build and renovated schools in 1996. Conservatives argue that there is no federal role in school facilities and that it should remain solely a state and local function. Liberals fall into a "Washington knows best" trap and support needlessly Byzantine proposals that frequently ignore the reality of public school finance. ${ }^{54}$

President Clinton's proposed program at that time would have leveraged $\$ 34.5$ billion over five years by providing federal income tax credits to bondholders in lieu of interest payments made by communities. ${ }^{55}$ In 1995, the GAO estimated that the United States would need to spend $\$ 112$ billion to bring its schools up to date. ${ }^{56}$ H.R. 4094, also known as the Johnson-Rangel compromise and based on President Clinton's plan, would have provided Oklahoma an estimated \$277 million in allocations. During that final year in office, the Clinton administration kept as part of its education package a proposal to begin funding school construction.

\footnotetext{
${ }^{54}$ Mead, Sara School Construction. Policy Report. Progressive Policy Institute. Washington, DC. (ERIC Document Reproduction Service No. ED 458785). Also available: http://www.pionline.org/ppi_ci.cfm?knlg. (2001).

${ }^{55}$ United States Department of Education 2000.

${ }^{56}$ Education Commission of the States, 1998.
} 
During the $108^{\text {th }}$ congress, Representatives Johnson (R-Conn.) and Rangel (D-N.Y.) introduced a bill to provide tax credit for state and local school construction revenue bonds. They had 230 bipartisan cosponsors and more commitments for floor votes. The bill would have provided $\$ 3.57$ billion per year ( $\$ 1.1$ billion more than H.R. 4094) in leveraging tax incentives to generate more than $\$ 22$ billion annually for state and local school construction revenue bonds. ${ }^{57}$ The bill's inclusion of Davis-Bacon coverage (wage determinations issued by the Department of Labor) triggered opposition.

The above bipartisan plans work because they offer tax incentives to bondholders rather than having local school districts pay interest on the bonds. Interest on school construction bonds is often equal to the amount being spent on the actual construction. This type of innovative funding is unique because it avoids more federal programs and limits bureaucracy. This type of federal assistance would be of little value to the Jones School District used in the earlier example.

\section{Equity in Capital Outlay Policies}

School construction and facility maintenance legislation at the state level has increased in the last few years; however, unlike at the federal level, it appears that many states are making progress. Capital

${ }^{57}$ HVACMALL.com 2003. 
outlay bills passed by state legislatures increased dramatically in the 1990s. ${ }^{58}$ Eighteen infrastructure-funding bills in 1994 increased to 70 by 1997. During the 1999 legislative session, 93 bills were passed in 35 states. $^{59}$ The amount states contribute to school construction and repair varies. As a whole, state level contributions exceed $\$ 29$ billion annually. ${ }^{60}$ However, capital outlay funding at the state level is the exception rather than the rule. ${ }^{61}$ State legislatures have more than just funding to account for when considering school construction. Most states have technology plans, yet few have state construction plans. McColl and Mallhoit ${ }^{62}$ list five areas that legislatures must consider in developing a state school construction plan. States should use a building needs assessment to determine funding priorities. Arizona and Wyoming have used outside evaluators to conduct a needs assessment while Colorado, Nevada, and West Virginia have established

${ }^{58}$ See note 1 above.

${ }^{59}$ Crampton, F.E., "Financing Education in the Twenty-First Century: What State Legislative Trends of the 1990's Portend" Journal of Education Finance 27 (Sumer 2001), 479-500.

${ }^{60}$ See note 1 above.

${ }^{61}$ Maiden, Jeffrey Funding School Infrastructure in Rural America. Saving America's School Infrastructure. (2003). 129-146.

${ }^{62}$ McColl, A. \& G.C. Malhoit, Policy Brief. Rural School Facilities: State Policies the Provide Students with an Environment to Promote Learning. Rural Trust Policy Brief Series on Rural Education. (2004). 
internal, state-level entities to conduct the assessments. ${ }^{63}$ In a review of legislative trends in education finance, Crampton discusses a school building inspection resource manual that was funded by the Utah legislature. The manual is used to assist districts in recognizing and managing building and maintenance needs. The review process should have a mechanism in place to respond quickly to urgent needs, and the process should be non-competitive.

Rural districts are often at a disadvantage when competing for large grants because they do not have the resources in place that the larger districts do. Most urban and suburban districts have grant writers on staff who not only become aware of opportunities more quickly, but also can designate more personnel to the task of writing, developing and submitting documentation sooner than rural districts. State legislatures must also consider funding mechanisms to include methods for dispersion and creating revenue sources according to McColl and Mallhoit.

Direct aid provides the best opportunity to ensure equity as states can apply a formula when distributing the funds. This type of dispersion would best serve the rural schools. Similar to direct aid is aid for debt service. When dispersing funds through this mechanism, states pay

${ }^{63}$ Education Commission on the States 1998. 
down the principle and interest over time rather than a one-time contribution. Here again, states have a good opportunity to maintain equity. Matching grants, interest-free state loans, and mixed approaches are other options. Each of these options gives the state a little more ability to maintain equity.

When creating revenue, states again have several options. Besides general obligation bonds (from either the state or local level), states can fund capital outlay from the general revenue, local sales tax, or other use taxes. The key to maintaining fiscal security, however, is diversity in revenue. "Diversity in revenue sources has kept Washington's school construction program solvent for 56 years.",64 Washington uses timber sales, real estate development, the state lottery and bonds to fund schools. California uses impact fees. This is a tax imposed on new construction as a regulatory tool to ensure infrastructure growth in pace with commercial construction. State building standards should be set to ensure safety and accommodate technology and innovation. The final two items states must consider are designating responsibility for oversight and establishing an evaluation process. According to McColl and Malhoit, states must consider and set tough

${ }^{64}$ Joyner, Amy Funding Facilities A Billion - Dollar Building Boom. Education Vital Signs. [on-line]. Available:

http://www.asbj.com/evs/04/fundingfacilities.html. (2004). 
ethical standards to avoid conflicts of interest. States will need to determine whether a state or local agency should be responsible for monitoring the process.

\section{$\underline{\text { Summary }}$}

Education finance policy has been transformed through the courts from a way to provide classrooms, teachers, and books to local communities to a process for eliminating the various circumstances in life that hinder a child's potential. Education finance reformers in the landmark Serrano case relied heavily on documentation of inadequate buildings and facilities. As cited earlier, this began decades of equalizing the system by providing more funding to districts that could not generate it locally. This funding, however, was applied to classroom needs. The assumption was that better books, equipment, and teacher salaries would result in better pedagogy. While some marginal research has been offered on how school environment affects student outcomes, little research is available on the effect of capital outlay funding on student achievement or school performance. Capital outlay funding is critical as most school buildings reach 40 and 50 years in operation. New research should focus on the correlation between facilities and accomplishment of policy objectives including student achievement. 


\section{Chapter 3}

\section{Study Design}

This chapter presents an introduction to the study design followed by a description of the context for the study. A presentation of data collection procedures and the methodology used to analyze the data is included.

\section{$\underline{\text { Introduction }}$}

States continue to face problems providing sufficient facilities for education. The American Association of School Administrators and the United States General Accounting Office have each cited $\$ 100$ billion as the amount needed to overcome these facility issues. ${ }^{65}$ Most rural schools face building needs, and in $1996,52 \%$ of rural school facilities had at least one inadequate structural or mechanical feature. ${ }^{66}$ Each state funds facilities differently; however, $96 \%$ of the local taxes raised for education during fiscal year

\footnotetext{
${ }^{65}$ Houston, P.D. American Association of School Administrators in forward to School Bond Success: A Strategy for Building America's Schools, by Holt, C.R. (Lanham. Scarecrow Press. 2002).

${ }^{66}$ National Center of Educational Statistics, 2000, p.2.
} 
1994-1995 came from property taxes. ${ }^{67}$ Property taxes often reflect the wealth or lack of wealth of a community.

Students across the country are attending school in facilities that are substandard for their purpose. This is not a problem unique to rural communities; however, one element of this exploratory study is the examination of the effect capital outlay funding mechanisms in Oklahoma have on school districts according to rurality. This study is designed to demonstrate how socioeconomic status, property wealth, and local support for building projects differ in rural and non-rural districts and if any differences determine if students attend school in districts that spend less on buildings and facilities. This study will also explore how these same funding mechanisms affect student achievement.

Oklahoma's 540 independent school districts are used as units of analysis. Each district was used to determine the following variables: bond passage rates, per pupil capital outlay expenditures, net assessed valuation per pupil, metropolitan statistical area designation as rural or non-rural, socioeconomic status, and achievement as determined by the Academic Performance Index. These variables were selected after an examination of Oklahoma's public school capital outlay funding system within the context of rural communities.

${ }^{67}$ Ladd, H.F. \& Hansen, J.S., ed., Making Money Matter: Financing America's Schools. Committee on Education Finance. (Washington, D.C. National Academy Press. 1999). p. 54-55. 


\section{Context}

As a study of this type would become too cumbersome if done on a national scale, a single state was chosen as the source of data for this study. Oklahoma was selected as the context for this study because it provides a large rural school population, heavy reliance on property tax, and modest student achievement results. Oklahoma also has a detailed school accounting system that provided plenty of data. A contextual discussion of Oklahoma follows including detailed demographic data, a history of education reform, and a description of the department of education and school finance system.

\section{Oklahoma's demographic picture}

Oklahoma's 70,000 square miles rank $18^{\text {th }}$ in land size; however, its 2004 total population of $3,523,553$ ranked $28^{\text {th }}$. The student population in 2006 was 639, 014, having increased from 588,223 in 1986 (8.63\% increase over 20 years). There was a corresponding $21.7 \%$ increase nationally during this same

period. ${ }^{68}$ Oklahoma is a rural state with a student population growth rate slower than the national average. Oklahoma's special education program serves 96,000 children, and 45,000 live in a home where the primary language is not English. Of Oklahoma's 641,721 schoolchildren, 55.2\% qualify for free or reduced

${ }^{68}$ Snyder, T.D. \& Hoffman, C.M. State Comparisons of Education Statistics: 1969-70 to 1996-97. National Center for Education Statistics. NCES 98-018. Washington DC. 1998. 
lunches. Despite the 14,000 school age children who are enrolled in an alternative education program, there is still a 3.3\% dropout rate in 2005-2006. This rate is up from $3.2 \%$ in $2004-2005$.

Oklahoma's significant rural population included 462,000 households in 2005 compared to twice as many urban households at 919,000. Even as they fewer in number than urban households, rural households include an average of 2.6 people while urban households have only 2.4 people. There are fewer households, but each houses more occupants. Rural communities also have an older population than urban communities. Close to half $(43 \%)$ of rural residents are 45 years old or older while only $35 \%$ of urban residents fall in this same age range. This is significant because Oklahoma requires a $60 \%$ supermajority to pass bond issues. It is fair to assume that most people in this age range do not have children in school; therefore, school administrators are often trying to sell bond proposals to a large population without children in school. The number of owner occupied residences in rural communities is another obstacle when trying to pass bond issues. Owner occupied homes account for only $82 \%$ of households in rural communities while urban communities have $61 \%$ owner occupancy. Owners feel a more direct impact of additional taxes, and they often will pay for multiple properties. 


\section{History of Education Reform in Oklahoma}

Although there was some attention given to teacher improvement and professional development, Oklahoma education policy-makers were somewhat slow to respond during the national reform measures of the $1980 \mathrm{~s}^{69}$ In May 1989, Oklahoma governor Henry Bellmon signed HJR 1003 to form "Task Force 2000." This legislation became HB 1017, a significant piece of legislation for Oklahoma's public schools. The legislation enjoyed strong, bi-partisan support; however, supporters failed twice to pass the emergency clause required to secure immediate enforcement. Soon the controversy and massive demonstrations led to a teacher walk-out, and the legislation was signed into law on April 25, $1990 .^{70}$ More opposition after the bill was signed into law brought a referendum petition to the state capitol. After the issue was given to a vote of the people, it passed with $54 \%$.

The reforms of HB 1017 include student performance, compensation and training of teachers, accountability and structure of schools, and funding issues. A study of HB 1017 conducted in 1992 surveyed rural school administrators to determine the impact of these reforms on rural schools in Oklahoma. Chance

${ }^{69}$ Keller, Bess. Oklahoma's public schools have made genuine progress since 1990, but reform efforts have a long way to go. Education Week: Quality Counts 97. http://counts.edweek.org/sreports/qc97/states/ok.htm.

${ }^{70}$ Chance, Edward W. The Impact of Oklahoma House Bill 1017 on Rural Education: A Study of Selected Schools. Department of Educational Leadership and Policy Studies. The University of Oklahoma. 1992. 
reports in the adequacy section of that study that additional building of classroom space was the most frequent explanation for reporting "not adequate funding" on the survey. ${ }^{71}$ HB 1017 may have had a significant effect on school consolidation in Oklahoma. At the time HB 1017 went into effect, there were 604 school districts in Oklahoma. The number was down to 573 when the Chance study was released. $^{72}$

\section{Oklahoma Department of Education}

The Oklahoma Department of Education is a large government agency responsible for the oversight of 540 districts with 1851 school sites. The state began in 1907 with 5,656 districts and grew to 5,889 in 1913. While Oklahoma ranks near the bottom in teacher pay ( $48^{\text {th }}$ in 2007 ), there is evidence of a quality teacher work force. Of the state's 49,000 teachers, 1569 are National Board Certified ranking 8th in the nation in 2006.

Each year the State Department of Education publishes the Invest in Oklahoma Report. Volume 10 of that report issued in January 2007 listed four major educational difficulties facing Oklahoma. Those four issues include preparing students for college and the workplace, demographic changes, accountability of programs and schools, and investing in a world class public

\footnotetext{
${ }^{71}$ Ibid.

${ }^{72}$ Ibid.
} 
education for all children. While these topics seem broad in scope, none suggest the need for new or renovated facilities. ${ }^{73}$

Oklahoma student achievement lags behind most of the country. Oklahoma's $87 \%$ of $18-24$ year olds with a high school diploma ranks $30^{\text {th }}$ in the nation. ${ }^{74}$ Since the implementation of HB 1017, there has been no significant increase on state or national tests; ${ }^{75}$ however, Oklahoma has had increases in ACT participation. In the last five years, $23 \%$ more black students, $7 \%$ more American Indian students, and $43 \%$ more Hispanic students have taken the ACT. Since 2000 , Oklahoma $4^{\text {th }}$ and $8^{\text {th }}$ grade students have each scored above the national average on NAEP testing only once. Both occasions were reading tests. Oklahoma appears to be making progress with rigorous high school instruction as Advanced Placement participation and scores have increased since HB 1017.

Academic Performance Index

Important to a contextual understanding of Oklahoma's school curriculum is a discussion of the Academic Performance Index (API). API is

\footnotetext{
${ }^{73}$ Oklahoma State Department of Education. Investing in Oklahoma: The Progress of Education Reform. V10. 2007.

${ }^{74}$ Keller, Bess. Oklahoma's public schools have made genuine progress since 1990, but reform efforts have a long way to go. Education Week: Quality Counts 97. http://counts.edweek.org/sreports/qc97/states/ok.htm. ${ }^{75}$ ibid
} 
also a variable for this study; however, it is important to introduce the concept with this discussion of Oklahoma's public school performance. The API is the accepted gauge for school performance in Oklahoma. It is a comprehensive formula, but not too unlike those in many other states.

The Oklahoma API is similar to other performance indicators used around the country to determine adequate yearly progress (AYP), a product of No Child Left Behind. The Oklahoma legislature implemented 70 O.S. § 3-150 which required the department of education to measure the performance of Oklahoma schools, based on several factors that contribute to overall educational success. The API is a numerical index, or score, ranging from 0 to 1500 , with 1000 as the 2001-2002 state average. Based primarily on state test scores $(60 \%)$, the index incorporates seven areas that were determined to cause "educational success."76 As the API is a complex formula, it is important for the reader to understand the various elements and their relationship to the final score. The stated emphasis of the API is growth. Schools and districts are expected to increase their score every year. The seven factors included in the formula are divided into three components.

\footnotetext{
${ }^{76}$ Oklahoma State Department of Education. Academic Performance Index (API) 2001-2001: Overview. 2002.
} 
1. Oklahoma School Testing Program (OSTP).

a. Reading and mathematics results from grades 3,5 , and 8 .

b. English II, Algebra I, American History, and Biology scores from End-of-Instruction tests in high schools.

2. School Completion
a. Attendance rates
b. Graduation rates
c. Dropout rates

3. Academic Excellence
a. ACT scores
b. ACT participation
c. Advanced Placement participation
d. College remediation rates in reading and math

As not all district or school types are responsible for all the components, a weighting system is used: 
Table 1 API Weighting System

\begin{tabular}{ccccc}
$\begin{array}{l}\text { School / } \\
\text { District Type }\end{array}$ & \multicolumn{1}{l}{$\begin{array}{l}\text { Core Grade } \\
\text { Span }\end{array}$} & $\begin{array}{l}\text { Testing } \\
\text { Program } \\
\text { (OSTP) }\end{array}$ & $\begin{array}{l}\text { School } \\
\text { Completion }\end{array}$ & $\begin{array}{c}\text { Academic } \\
\text { Excellence }\end{array}$ \\
\hline K-12 & K-12 & $80 \%$ & $10 \%$ & $10 \%$ \\
K-6 & K-8 & $90 \%$ & $10 \%$ & N/A \\
High School & $9-12$ & $80 \%$ & $10 \%$ & N/A \\
Middle Sch & $7-8$ & $90 \%$ & $10 \%$ & $10 \%$ \\
Elem School & K-6 & $90 \%$ & $10 \%$ & N/A \\
\hline
\end{tabular}

The scores range from 0 to 1500 . Baseline data were established in 2001-2002, with 1000 as the state average. Within each of the components are other indicators that yield scaled scores that are weighted and combined to arrive at the component score. These component scores are weighted as shown above to produce the Total API. The following explanation is provided by the Oklahoma State Department of Education:

The Total API, as well as each Interim and Component API, is calculated by first establishing a Reasonable Limit Value (RLV) and multiplier for each indicator. The RLV is established by analyzing historical data patterns to determine an attainable goal; when the RLV for a specific indicator is achieved, the Interim 
API score will be a "perfect" 1500. The multiplier for each indicator converts varying data (which, in its original form, would be impossible to compare) into a comparable and combinable number on the 0 to 1500 API scale. The formula for determining the multiplier for each indicator is as follows:

Multiplier $=$ API Upper Limit (1500) - API Average (1086 in 2004)

Indicator RLV - State Indicator Value

API Value $=($ School Indicator Value - State Indicator Value $) X$ Multiplier +1086

The Oklahoma State Department of Education also oversees a large Career Technology program. Formerly known as vocational technology, CareerTech serves $85,000(48 \%)$ of the states high school students. Of the state's 540 districts, 400 offer CareerTech programs, and the state supports 54 individual CareerTech facilities. CareerTechs fund facilities through bond issues also; however, they often serve several districts and enjoy wide support. HB 1017 also changed the state funding formula in an attempt to improve equity.

The Oklahoma school funding formula provided \$1,746,626,795 through state aid to Oklahoma schools in 2005-2006, representing $75.75 \%$ of the total state-appropriated funds. Total state-appropriated funding has increased $165 \%$ since HB 1017. The state has recently witnessed severe budget shortfalls. In 
2001-2002 schools lost 103.4 million in funds. The following year they lost 106.4 million.

The Oklahoma state aid funding formula was originally constructed in 1981 and went through significant changes in 1990 and 1996. Real, personal, and public service property provide the basis of ad valorem tax in Oklahoma. Property values are determined by each county assessor. Oklahoma uses an assessment ratio of $11 \%$ to determine the assessed value of property. Oklahoma limits the amount of the assessed valuation that may be used for bonded indebtedness at $10 \%$. Property owners also receive a $\$ 1000$ property tax exemption for their primary residence. This "Homestead Exemption" is quite high for many rural areas as the homes are generally of modest size and value. A rural district with an assessed valuation of $\$ 1,000,000$ for 100 homes would loose $\$ 100,000$ or $10 \%$ in "Homestead Exemption". A wealthier sub-urban district with an assessed valuation of $\$ 5,000,000$ for 100 homes would also loose $\$ 100,000$; however, this would be only $2 \%$ of the assessed valuation. $10 \%$ of the assessed value less the homestead exemption is the net assessed value (NAV) for a district. Districts may request any portion of this NAV. Percent of bonding capacity is important in Oklahoma beyond capital outlay considerations. Districts at $85 \%$ capacity or higher are exempt from class size requirements. 
Recently, the Oklahoma legislature passed a law allowing city governments to ask voters to pass sales tax measures in support of capital outlay for local schools. This option eliminates the supermajority requirement because it is a simple city government tax issue. While this option is available to all cities, it is of little practical value to small communities that generate few sales tax dollars. This option has been pursued by many of the large districts; the most successful example of which is the Oklahoma City Maps for Kids campaign. These funds were divided 70/30 with surrounding districts based on Oklahoma City resident student enrollment.

General operating expenses are also generated through property taxes. $\$ .03 .9$ of every dollar of assessed value is deposited into the general fund. These dedicated revenues are charged against each district prior to state aid being granted. This balance of local and state effort provides the foundation for vertical equity.

As this is an exploratory study, the intention was to better understand the various relationships among the funding mechanisms. The research questions for this exploratory study are:

1. Is there a statistically significant difference in each of the following indicators of district capacity to meet capital outlay needs among Oklahoma districts according to Metropolitan Statistical Area classification? 

a. Bond passage rates
b. Per pupil capital outlay expenditures
c. Net assessed valuation per pupil

2. Is there a statistically significant relationship between district socioeconomic status and the following indicators of local district ability to meet capital outlay needs in Oklahoma?
a. Bond passage rates
b. Per pupil capital outlay expenditures
c. Net assessed valuation per pupil

3. What is the predictive power of each of the following district characteristics on capital outlay expenditures per pupil in Oklahoma?
a. Bond passage rates
b. MSA designation
c. District SES

4. Is there a statistically significant relationship between each of the following district characteristics and achievement among Oklahoma school districts?
a. Bond passage rates
b. MSA designation
c. District SES
d. Capital outlay expenditures per pupil 


\section{Data Collection}

Data were collected through the Oklahoma State Department of Education. Per pupil capital outlay expenditures were determined using the Oklahoma Cost Accounting System and the unweighted average daily membership (ADM). Expenditures entered under codes: 2600's, 2720, 2740, 2790, and 4000's, reflect capital outlay expenditures. Unweighted average daily membership was chosen over weighted average daily membership as there is no significant difference between the two. ${ }^{77}$ The bond issue passage rate data was collected from county election boards. Each of the 77 county elections boards in Oklahoma was contacted, and a request was made for all special bond election results for 2001 - 2006. Election boards from 70 counties responded with complete results.

All dollar figures were adjusted for rate of inflation by using the consumer price index (CPI) provided by the United States Department of Labor: Bureau of Labor Statistics. The February 2007 CPI for all urban consumers was 203.499. February 2002 CPI was 177.8 . This resulted in a point change of 25.699. This point change divided by the previous index (177.8) is .145. A percentage change of $14.45 \%$ was used to calculate rate of inflation of 2002

${ }^{77}$ Maiden, J. and R. Stearns. "Fiscal Equity Comparisons Between Current and Capital Education Expenditures and Between Rural and Nonrural Schools in Oklahoma," Journal of Education Finance 33 (2007): 147-169. 
dollars to 2007. A similar process was used for each subsequent year. ${ }^{78}$

Inflation adjusted dollar amounts were used because of the need to compare increases or decreased (growth) over time of real value. Nominal dollar values would provide only a snapshot of the relative differences for a specific time and would not allow for a common reference over time.

Each statistical model used data from the years 2001-2007, which includes the range of available API data. These API data were paired with the previous year's financial data. This is necessary because API data reported for a given year is based on testing data from the previous year. This five year period is also the most common bond repayment schedule. It can be assumed that most districts had the opportunity to request bond issues during this time.

\section{Methodology}

Research question 1 was addressed through the use of three separate independent samples t-tests. Metropolitan Statistical Area (MSA) classifications, used by the United States Census Bureau to reference population density, were used to determine rural and non-rural districts. United States Census Bureau uses micropolitan statistical area and metropolitan statistical area

\footnotetext{
${ }^{78}$ United States Department of Labor: Bureau of Labor Statistics web site was used for data and method of calculation. http://data.bls.gov/cgi-bin/surveymost and http://www.bls.gov/news.release/cpi.nr0.htm.
} 
as defined by the Office of Management and Budget effective June 6, 2003. ${ }^{79}$ In general, these areas are determined by a geographic region around a "substantial" population nucleus. This geographic region shares significant economic and social integration with the "population nucleus."

One can see how this has an affect on property values. Of Oklahoma's 77 counties, 44 are rural, 18 are micropolitan, and 17 are metropolitan. Any MSA not classified as rural was categorized as non-rural. The purpose of this exploratory study is to determine if rural schools are at a disadvantage. Distinguishing other MSA classifications was not beneficial beyond providing a comparison for rural districts. Therefore all other classifications were combined. For the current study, MSA classification was used as an independent variable for the t-tests. The t-test is designed to demonstrate any statistical difference in the means of two groups. In other words, do the two groups differ in their respective relationship with each dependant variable?

Each group rural and non-rural was analyzed using one of four dependent variables. The three dependent variables used for the three independent samples t-tests include bond issue passage rates, capital outlay available per pupil, and net assessed valuation per pupil.

\footnotetext{
${ }^{79}$ United States Census Bureau. "About Metropolitan and Micropolitan Statistical Areas." http://www.census.gov/population/www/estimates/aboutmetro.html.
} 
Bond issue passage rate was chosen as a dependant variable for this model because it will contribute data that demonstrates effort at the local level. Bond issue passage rates include the percent of yes votes a district received on a bond proposal each year. If a district did not put forward a bond issue, no data were entered. Districts are under no limit of bond issues put before voters. The only limit is bonding capacity. Some districts attempt to bond the entire capacity in one election. Others request some percentage of total capacity more regularly. Bond passage rates in this study were used as a determiner of local support; therefore, only percentage of approvals was necessary. The five year period is accurate as most bond issues are issued on a five year repayment schedule.

Net assessed valuation (NAV) per pupil was determined by dividing each district's average daily membership into total NAV for each district. This variable allows capacity to be analyzed by district size and is shown as NAV. Bonding capacity (CAP) was determined by each district's property values. The amount of NAV that was currently available and not tied up in a current project was used as bonding capacity. NAV and CAP were selected as dependant variables because each provides data reflecting resources in proportion to district size. This model is designed to show any differences between rural districts and non-rural districts ability to fund capital outlay needs. 
Research question 2 was addressed using the Spearman rank correlation coefficients. Correlation matrices using percent free and reduced lunch as the primary variable were examined. The additional variables used were bond issue passage rate, NAV, and CAP. The percent of free or reduced lunches in each district was used as a proxy for socio-economic status. This is a commonly used variable for this purpose within the education research. This model is valuable to this exploratory research because it measures the relationship between relative household wealth and key capital outlay funding mechanisms.

The Spearman rank correlation coefficient is a standardized version of the covariance. ${ }^{80}$ It determines the presence, strength, and type of relationship between two variables. Spearman rank correlation works by converting the variables into ranks thereby reducing the effects of non-normality. After ranking, a correlation analysis is done and the correlation coefficient ( $\mathrm{r}$ ) is determined. The significance is tested, and the P-value is determined. Spearman rank correlation is used to determine if the variables are related, and if so determined, the strength of the relationship.

Research questions 3 and 4 were addressed using two regression analyses. A multiple linear regression model was used to test the power of the independent variables rural / non-rural, SES, NAV, and bond passage rates on

\footnotetext{
${ }^{80}$ Lomax, Richanrd G. An Introduction to Statistical Concepts for Education and Behavioral Sciences. Lawrence Erlbaum Associates, New Jersey. 2001.
} 
the dependent variable COE for each district in Oklahoma. This model is similar to the Spearman rank correlation coefficients except that this model provides a measure of the predictive power of this group of variables on the amount of capital outlay dollars per pupil.

A second multiple linear regression model was used to test the power of the independent variables rural / non-rural, SES, NAV, capital outlay expenditure per pupil, and rates of bond passage on the independent variable API for each district in Oklahoma. Cost per graduate, dropouts, rigor, and attendance are all accounted for within the API. These are issues cited by Mathis as problems interfering with the use of test scores as an outcome measure when attempting to assess adequacy within funding mechanisms. ${ }^{81}$ The inclusion of these variables within the Oklahoma API makes the API variable more accurate than simple student tests scores for this exploratory research. This model demonstrates the effect that these capital outlay mechanisms have on school performance.

\section{$\underline{\text { Summary }}$}

Chapter three provided context for the study by detailing each variable and its association to capital outlay funding in Oklahoma and demonstrating

\footnotetext{
${ }^{81}$ Mathis, William J. "Financial Challenges, Adequacy, and Equity in Rural Schools and Communities," Journal of Education Finance. 29 (summer 2003), 119-136.
} 
how each variable serves as a mechanism within the entire system of funding. These analyses were designed to establish a logical progression from distinguishing unique variables (t-tests in question 1) to relationship among the variables (correlations in question 2) to predictive power (regressions in questions 3 and 4). This chapter described the statistical model and analyses used for each guiding research question. These models were used together to assist in a better understanding of how capital outlay funding is affected by demographics and funding rules. 


\section{Chapter 4}

\section{$\underline{\text { Results }}$}

The previous chapter presented the study design and identified the variables. This chapter presents the results of the analysis. A brief overview of the study is presented followed by the descriptive statistics. Each research question is presented in order. A table listing the results of the statistical analysis is provided with each research question.

The purpose of this study was to explore how the various funding mechanisms in Oklahoma interact and influence school districts capital outlay spending. Specifically, this study was designed to examine how capital outlay funding in Oklahoma is affected by community support, degree of rurality, and demographics. Community support was designated as bond passage rates. Demographics include poverty and local wealth. Poverty was designated as socio-economic status (SES) with high SES representing high levels of poverty, and local wealth was designated as net assessed valuation in the variables. Each variable is explained in detail in the previous chapter. The study also reflects the interaction of these funding elements on school and student performance as determined by the Academic Performance Index. These variables were analyzed through the use of t-tests, correlations, and regression analyses. All 
financial data was adjusted for rate of inflation by using the consumer price index. This process was explained in chapter three.

This chapter provides the results of the data analysis for the study. Data collected for this study included fiscal years 2001 through 2005 for all variables except academic performance index. The API variable included years 2002 through 2006, as the API was determined at the conclusion of each school year. Other variables included socio economic status, capital outlay expenditures, net assessed valuation, and percentage of approval on special school bond elections. The results are presented through descriptive, t-test, correlation, and regression results.

\section{$\underline{\text { Sample Characteristics }}$}

The sample contained 540 school districts in Oklahoma. School districts that consolidated during the period of years studied were not included as there were not sufficient data. Also, cooperatives and charter schools that formed during the years of study were not included.

\section{Descriptive Statistics}

Table 1 presents descriptive statistics for the original variables for each

of the 5 years of measurement, as well as measures of skewness and kurtosis. 
Both finance variables, COE and NAV, have large standard deviations for all years. The COE mean shows no pattern for growth; however, COE standard deviation declines each year until 2005 when the result is the highest of the five years. NAV results for mean, standard deviation, and max grow steadily for each of the five years. The difference in dispersion of NAV across all districts is more then $200 \%$ larger between 2003 and 2004 than for other years. The difference between 2003 and 2004 NAV standard deviation is $\$ 16,805.37$. The difference between 2001 and 2002 is $\$ 1,689.09$. The difference between 2002 and 2003 is $\$ 3,633.40$ and $\$ 5,036.21$ between 2004 and 2005 . For the five years analyzed, property values rise while capital outlay expenditures generally decrease except for the final year of data, 2005.

Level of poverty increased slightly over the five years beginning with $59.6 \%$ free / reduced lunch participation in 2001 and rising to $63.2 \%$ participation in 2005. The standard deviation for SES decreased over all years measured demonstrating less dispersion for that variable.

The percentage of districts participating in bond issues varies from $23.7 \%$ in 2001 to $15.1 \%$ in 2002 . The percentage of yes votes varies slightly from $73.5 \%$ in 2001 to $69.1 \%$ in 2002.

Not all districts reported Academic Performance Index for all years. Districts reporting data ranged from 520 to 536. District API scores show 
growth for each year reported. Standard deviation varied from year to year. 2003 API scores showed the greatest dispersion and the lowest minimum and maximum score. Skewness and kurtosis both show growth for each year reported.

Preferred skewness and kurtosis values fall within the range of -2 to +2 , although it is acceptable to have some higher kurtosis levels as long as they are within -10 to +10 . As can be seen in Table 2 , the COE and NAV variables did not exhibit acceptable levels of skewness or kurtosis, indicating that these variables were not normally distributed. Because normality is an assumption of many statistical tests, these variables required transforming before they could be used in further analyses.

The COE and NAV variables were log transformed to make them more normal. The COE variables contained some zero values. Zero values cannot be $\log$ transformed; therefore, a value of 1 was added to each score for each $\mathrm{COE}$ variable before transforming. The resulting values were log transformed. NAV variables were log transformed as well. Table 3 presents descriptive statistics for the transformed COE and NAV variables. All skewness and kurtosis levels were brought into the acceptable range by transformation.

After transformation, COE patterns changed slightly. Log transformed values no longer showed a general decline in standard deviation. Instead values 
Table 2. Descriptive Statistics for Original Variables

\begin{tabular}{lccccccc}
\multicolumn{1}{l}{ Variable } & $N$ & Mean & $S D$ & Min & Max & Skew & Kurtosis \\
\hline COE 1 & 540 & $\$ 252.54$ & $\$ 549.98$ & $\$ 0$ & $\$ 6768.90$ & 6.244 & 56.592 \\
COE 2 & 540 & $\$ 250.61$ & $\$ 499.88$ & $\$ 0$ & $\$ 6339.10$ & 5.266 & 46.104 \\
COE 3 & 540 & $\$ 282.14$ & $\$ 495.49$ & $\$ 0$ & $\$ 4028.90$ & 3.226 & 13.704 \\
COE 4 & 540 & $\$ 260.30$ & $\$ 482.21$ & $\$ 0$ & $\$ 4841.00$ & 4.119 & 26.056 \\
COE 5 & 540 & $\$ 313.27$ & $\$ 558$ & $\$ 0$ & $\$ 5880.30$ & 4.152 & 26.842 \\
NAV 1 & 540 & $\$ 24648.96$ & $\$ 27329.17$ & $\$ 3048$ & $\$ 481611$ & 9.762 & 148.218 \\
NAV 2 & 540 & $\$ 26440.42$ & $\$ 29018.26$ & $\$ 2461$ & $\$ 482228$ & 8.442 & 116.174 \\
NAV 3 & 540 & $\$ 28358.81$ & $\$ 32651.66$ & $\$ 2583$ & $\$ 543164$ & 8.668 & 118.840 \\
NAV 4 & 540 & $\$ 33581.09$ & $\$ 49457.03$ & $\$ 2292$ & $\$ 588657$ & 7.069 & 65.674 \\
NAV 5 & 540 & $\$ 34151.06$ & $\$ 54493.24$ & $\$ 2478$ & $\$ 905147$ & 9.889 & 133.923 \\
SES 1 & 540 & $59.6 \%$ & $18.5 \%$ & $0 \%$ & $100 \%$ & -.122 & .346 \\
SES 2 & 540 & $61.6 \%$ & $18.7 \%$ & $0 \%$ & $100 \%$ & -.029 & 1.384 \\
SES 3 & 540 & $62.4 \%$ & $17.4 \%$ & $0 \%$ & $100 \%$ & -.390 & .075 \\
SES 4 & 540 & $63.2 \%$ & $17.4 \%$ & $0 \%$ & $100 \%$ & -.452 & .103 \\
SES 5 & 540 & $63.2 \%$ & $17 \%$ & $0 \%$ & $100 \%$ & -.470 & .133 \\
Bond 1 & 128 & $73.5 \%$ & $14 \%$ & $20 \%$ & $100 \%$ & -.971 & 1.667 \\
Bond 2 & 82 & $69.1 \%$ & $15.1 \%$ & $20 \%$ & $100 \%$ & -.931 \\
Bond 3 & 90 & $69.6 \%$ & $12.2 \%$ & $30 \%$ & $90 \%$ & -.780 \\
Bond 4 & 104 & $71.1 \%$ & $14.9 \%$ & $20 \%$ & $100 \%$ & -.656 & .246 \\
Bond 5 & 102 & $69.4 \%$ & $15.2 \%$ & $20 \%$ & $90 \%$ & -.823 & .430 \\
02DIST & 528 & 973.85 & 130.706 & 601 & 1404 & -.081 & .218 \\
03DIST & 520 & 1022.39 & 153.038 & 319 & 1373 & -.795 \\
04DIST & 520 & 1065.28 & 145.251 & 389 & 1422 & -.804 & 1.725 \\
05DIST & 527 & 1138.67 & 147.123 & 461 & 1458 & -.899 & 1.729 \\
06DIST & 536 & 1192.35 & 132.795 & 574 & 1500 & -1.059 \\
\hline
\end{tabular}


Table 3 Descriptive Statistics for Transformed Variables $(N=540)$

\begin{tabular}{lcccccc}
\hline Variable & Mean & $S D$ & Min & Max & Skew & Kurtosis \\
\hline COE 1 T & 1.59 & 1.06 & 0.00 & 3.83 & -.33 & -1.15 \\
COE 2 T & 1.60 & 1.05 & 0.00 & 3.80 & -.36 & -1.14 \\
COE 3 T & 1.62 & 1.10 & 0.00 & 3.61 & -.32 & -1.26 \\
COE 4 T & 1.62 & 1.07 & 0.00 & 3.69 & -.37 & -1.15 \\
COE 5 T & 1.72 & 1.08 & 0.00 & 3.77 & -.46 & -1.07 \\
NAV 1 T & 4.29 & 0.28 & 3.48 & 5.68 & .54 & 1.39 \\
NAV 2 T & 4.31 & 0.20 & 3.39 & 5.68 & .49 & 1.37 \\
NAV 3 T & 4.34 & 0.28 & 3.41 & 5.73 & .64 & 1.63 \\
NAV 4 T & 4.37 & 0.32 & 3.36 & 5.77 & .89 & 2.22 \\
NAV 5 T & 4.39 & 0.30 & 3.39 & 5.96 & .90 & 2.82 \\
\hline
\end{tabular}

are mixed from year to year with a range of 1.05 to 1.10 . There are no other noticeable pattern changes for either finance variable.

\section{$\underline{\text { Research Question } 1}$}

Research question 1 asked: Is there a statistically significant difference in each of the following indicators of district capacity to meet capital outlay needs among Oklahoma districts according to Metropolitan Statistical Area classification?
a. Bond passage rates
b. Per pupil capital outlay expenditures
c. Net assessed valuation per pupil 
Research question 1 was addressed by computing a separate independent $t$-test comparing Rural to Non-Rural for the three dependent variables presented above for each of the 5 years.

Table 4 presents the results of the $t$-tests. There was no statistically significant difference between the two MSA classifications for bond passage rates (all $p \mathrm{~s}>.05$ ) for any of the 5 years. There were statistically significant differences between the MSA classifications for both COE and NAV for each of the 5 years. The COE values were significantly higher for Non-Rural every year, and NAV values were significantly higher for Rural every year.

Bond passage rates were used as a measure of local support, and this variable demonstrates that local support is the same in each area. Although nonrural means were slightly higher than rural means in 4 of the 5 years, both types of communities are generally supportive of bond issues. It is important to remember that this is a measure of the strength of the positive vote for an entire calendar year. A district may have on overall positive percentage of yes votes while still failing one or more bond issues during the year.

Capital outlay expenditure means were lower for rural districts for each of the five years, and the results were statistically significant. Standard deviations for this variable were mixed from year to year. Standard deviations for $\mathrm{COE}$ were higher for rural districts in 3 of the 5 years and lower once. Non- 
rural districts show a nominally higher standard deviation in 2003 with only a .07 difference.

Net assessed valuation was significantly higher for rural districts in each of the 5 years studied. Rural districts also had a much higher standard deviation for each of the 5 years. This high standard deviation demonstrates a wide

Table $4 t$-test results and $d f$

\begin{tabular}{cccccc}
\hline & Year 1 & Year 2 & Year 3 & Year 4 & Year 5 \\
\hline \multirow{2}{*}{ Bond } & -0.65 & -1.10 & -1.75 & -0.97 & 0.78 \\
& $(126)$ & $(26.5)$ & $(88)$ & $(38.1)$ & $(100)$ \\
COE & -5.00 & -2.83 & -2.69 & -4.19 & -4.75 \\
& $(460.4)^{* * *}$ & $(467.9)^{* *}$ & $(538)^{* *}$ & $(453.0)^{* * *}$ & $(468.7)^{* * *}$ \\
NAV & 3.09 & 3.30 & 2.93 & 2.60 & 2.50 \\
& $(415.7)^{* *}$ & $(409.8)^{* *}$ & $(417.5)^{* *}$ & $(417.8)^{*}$ & $(401.7)^{*}$ \\
\hline
\end{tabular}

$t$-tests were performed on the log transformed variables for COE and NAV. Variables with non-integer degrees of freedom did not pass Levene's test for equality of variances; therefore, the $t$-test for unequal variances was used. $* p<.05 . * * p<.01 . * * * p<.001$.

dispersion in NAV among the rural districts during this time. See Table 5 for standard deviations and means. Because three variables were used in the $t$-tests, a Bonferroni adjustment was considered. With this adjustment, all results remain significant except NAV for years 2003, 2004, and 2005. Those years would be significant at the $p<.05$ level. However, with only three variables, a 
slight change in significance, and the possibility for a type II error with this adjustment, those results are dismissed.

\section{Research Question 2}

Research question 2 asked: Is there a statistically significant relationship between district socio-economic status (amount of poverty) and the following indicators of local district ability to meet capital outlay needs in Oklahoma?
a. Bond passage rates
b. Per pupil capital outlay expenditures
c. Net assessed valuation per pupil

Research question 2 was addressed by computing Spearman rank correlation coefficients between SES and the three variables listed above. High measures of SES represent increased poverty. Table 6 presents the correlations between all pairs of variables, although the correlations that specifically address the research question can be found in column 1. Spearman rank correlations were used instead of Pearson correlations so that any deviations from normality would not play any role in distorting any of the correlations. Socio-economic status was not related to bond passage rates $(p>.05)$, but was significantly negatively correlated with both $\operatorname{COE}(p<.01)$ and NAV $(p<.001)$ COE and 
NAV were also positively correlated with each other $(p<.001)$ in 2001 and 2002, but COE and NAV were not significantly correlated in 2003 - 2005.

Table $5 t$-test Results Comparing MSA Classifications

\begin{tabular}{|c|c|c|c|c|c|c|}
\hline & \multicolumn{3}{|c|}{ Rural } & \multicolumn{3}{|c|}{ Non-Rural } \\
\hline & $N$ & Mean & $S D$ & $N$ & Mean & $S D$ \\
\hline \multicolumn{7}{|l|}{ Year 1} \\
\hline Bond & 33 & 0.72 & 0.14 & 95 & 0.74 & 0.14 \\
\hline $\mathrm{COE}$ & 228 & 202.87 & 517.73 & 312 & 288.84 & 570.49 \\
\hline NAV & 228 & 29042.97 & 37409.26 & 312 & 21437.95 & 15763.05 \\
\hline \multicolumn{7}{|c|}{ Year 2} \\
\hline Bond & 20 & 0.65 & 0.18 & 62 & 0.70 & 0.14 \\
\hline $\mathrm{COE}$ & 228 & 244.37 & 608.53 & 312 & 255.17 & 403.40 \\
\hline NAV & 228 & 31782.34 & 39777.17 & 312 & 22536.70 & 16380.20 \\
\hline \multicolumn{7}{|c|}{$\underline{\text { Year } 3}$} \\
\hline Bond & 26 & 0.66 & 0.12 & 64 & 0.71 & 0.12 \\
\hline $\mathrm{COE}$ & 228 & 250.20 & 495.16 & 312 & 305.48 & 495.23 \\
\hline NAV & 228 & 33370.03 & 43553.39 & 312 & 24696.77 & 20768.14 \\
\hline \multicolumn{7}{|c|}{$\underline{\text { Year } 4}$} \\
\hline Bond & 29 & 0.68 & 0.19 & 75 & 0.72 & 0.13 \\
\hline $\mathrm{COE}$ & 228 & 231.59 & 503.08 & 312 & 281.28 & 466.07 \\
\hline NAV & 228 & 39128.96 & 55102.44 & 312 & 29526.89 & 44541.68 \\
\hline \multicolumn{7}{|c|}{ Year 5} \\
\hline Bond & 34 & 0.71 & 0.15 & 68 & 0.69 & 0.15 \\
\hline $\mathrm{COE}$ & 228 & 258.47 & 636.78 & 312 & 353.32 & 489.74 \\
\hline NAV & 228 & 41532.87 & 75305.32 & 312 & 28756.66 & 30629.63 \\
\hline
\end{tabular}

Note. Means and standard deviations are reported for original variables. 


\section{$\underline{\text { Research Question } 3}$}

Research question 3 asked: What is the predictive power of each of the following district characteristics on capital outlay expenditures per pupil in Oklahoma?
a. Net assessed valuation per pupil
b. Bond passage rates
c. MSA designation
d. District SES

Research question 3 was addressed by computing a multiple regression analysis in which COE was regressed simultaneously on the four predictor variables. For Year 1, the overall regression model was significant, $F(4,123)=4.64, p<.01$, and the four predictors together explained $13.1 \%$ of the variance in COE. For Year 2, the overall regression model was significant, $F(4,77)=5.36, p<.01$, and the four predictors together explained $21.8 \%$ of the variance in $\mathrm{COE}$. For Year 3, the overall regression model was not significant, $F(4,85)=1.95, p>$ .05 , and the four predictors together explained only $8.4 \%$ of the variance in COE. For Year 4, the overall regression model was significant, $F(4,99)=5.29$, $p<.01$, and the four predictors together explained $17.6 \%$ of the variance in COE. Finally, for Year 5, the overall regression model was not significant, $F(4$, $97)=2.10, p>.05$, and the four predictors together explained only $8.0 \%$ of the variance in $\mathrm{COE}$. 
Table 6 Spearman Rank Correlations between SES and Other Variables

\begin{tabular}{clcc}
\hline & SES & Bond & COE \\
\hline$\frac{\text { Year } 1}{\text { Bond }}$ & -.02 & -- & \\
COE & $-.14 * *$ & .14 & -- \\
NAV & $-.27 * * *$ & .00 & $-.16^{* * *}$
\end{tabular}

$\underline{\text { Year } 2}$

Bond

$-.08$

--

COE

$-.12 * *$

$-.03$

NAV

$-.29 * * *$

.08

$-.11 * *$

$\underline{\text { Year } 3}$

$\begin{array}{llll}\text { Bond } & -.18 & -- & \\ \text { COE } & -.13^{* *} & -.04 & -- \\ \text { NAV } & -.27 * * * & .11 & -.08\end{array}$

$\underline{\text { Year } 4}$

Bond

$-.13$

$--$

COE

$-.20 * * *$

$-.01$

NAV

$-.28 * * *$

.10

$-.05$

Year 5

Bond

$-.06$

$--$

COE

$-.17 * * *$

$-.08$

--
NAV
$-.27 * * *$
.14
$-.03$

Note. Original untransformed variables were used. $N=540$ for all correlations except for correlations with Approved Bond which varied as follows: Year 1: $N=82$, Year 2: $N=82$, Year 3: $N=90$, Year 4: $N=104$, and Year 5: $N=102$.

$* * p<.01 . * * * p<.001$. 
When all of the predictors were analyzed together, District SES was a significant predictor of COE for every year except Year 5. MSA was a significant predictor of COE for Years 1 and 4. Local support in 2001 and net assessed valuation in 2002 were the only values that demonstrated a positive regression coefficient. Both were small values when compared with other regression coefficients across all years, and neither was significant. See Table 7 for specific regression weights and significance levels.

\section{$\underline{\text { Research Question } 4}$}

Research question 4 asked: Is there a statistically significant relationship between each of the following district characteristics and achievement among Oklahoma school districts?
a. Net assessed valuation per pupil
b. Bond passage rates
d. MSA designation
e. District SES (amount of poverty)
f. Capital outlay expenditures per pupil

Research question 4 was addressed by computing a multiple regression in which DISTAPI was regressed simultaneously on the five predictor variables from the previous year. For example, for the first regression, DISTAPI from Year 2 was regressed on the predictors from Year 1. For Year 1, the overall 
Table 7 Regression Models for Predicting Capital Outlay Expenditures

\begin{tabular}{|c|c|c|c|c|c|}
\hline Predictors & $B$ & $S E B$ & $\beta$ & $R^{2}$ & $F$ \\
\hline \multicolumn{6}{|l|}{ Year 1} \\
\hline Net assessed & -0.52 & 0.41 & -.13 & .131 & 4.638 \\
\hline Bond passage rates & 0.73 & 0.64 & .10 & & \\
\hline MSA designation & -0.50 & 0.23 & $-.21 *$ & & \\
\hline District SES & -1.07 & 0.51 & $-.20 *$ & & \\
\hline \multicolumn{6}{|l|}{ Year 2} \\
\hline Net assessed & 0.15 & 0.52 & .03 & .218 & 5.364 \\
\hline Bond passage rates & -0.22 & 0.67 & -.04 & & \\
\hline MSA designation & -0.32 & 0.25 & -.14 & & \\
\hline District SES & -1.81 & 0.52 & $-.40 * *$ & & \\
\hline \multicolumn{6}{|l|}{ Year 3} \\
\hline Net assessed & -0.84 & 0.49 & -.19 & .084 & 1.952 \\
\hline Bond passage rates & -0.56 & 0.98 & -.06 & & \\
\hline MSA designation & -0.19 & 0.27 & -.08 & & \\
\hline District SES & -1.43 & 0.69 & $-.24 *$ & & \\
\hline \multicolumn{6}{|l|}{ Year 4} \\
\hline Net assessed & -0.04 & 0.38 & -.01 & .176 & 5.293 \\
\hline Bond passage rates & -0.43 & 0.57 & -.07 & & \\
\hline MSA designation & -0.42 & 0.21 & $-.20 *$ & & \\
\hline District SES & -1.67 & 0.50 & $-.33 * *$ & & \\
\hline \multicolumn{6}{|l|}{ Year 5} \\
\hline Net assessed & -0.17 & 0.41 & -.04 & .080 & 2.098 \\
\hline Bond passage rates & -0.40 & 0.67 & -.06 & & \\
\hline MSA designation & -0.31 & 0.23 & -.14 & & \\
\hline District SES & -1.16 & 0.62 & -.20 & & \\
\hline
\end{tabular}

Note. Log transformed variables were used for COE and NAV. The constants for the models are as follows: Year $1=4.07$, Year $2=2.24$, Year $3=6.47$, Year $4=3.26$, Year $5=3.62$. MSA was coded as $1=$ Rural and $0=$ Non-Rural. SES represents poverty not wealth. $* p<.05 . * * p<.01$. 
regression model was significant, $F(5,120)=16.48, p<.001$, and the five Year 1 predictors together explained $40.7 \%$ of the variance in DISTAPI Year 2. For Year 2, the overall regression model was significant, $F(5,75)=22.42, p<.001$, and the five Year 2 predictors together explained $59.9 \%$ of the variance in DISTAPI Year 3. For Year 3, the overall regression model was significant, $F(5$, $84)=14.88, p<.001$, and the five Year 3 predictors together explained $47.0 \%$ of the variance in DISTAPI Year 4. For Year 4, the overall regression model was significant, $F(5,96)=11.28, p<.001$, and the five Year 4 predictors together explained $37.0 \%$ of the variance in DISTAPI Year 5. Finally, for Year

5 , the overall regression model was again highly significant, $F(5,96)=16.70, p$ $<.001$, and the five Year 5 predictors together explained $46.5 \%$ of the variance in DISTAPI Year 6.

When all of the predictors were analyzed together, District SES was always a highly significant negative predictor of DISTAPI for every year (all $p \mathrm{~s}$ $<.001)$. COE was a significant predictor of DISTAPI for Year 2 only $(p<.05)$. NAV was a significant predictor of DISTAPI for Year 3 only $(p<.05)$. See Table 8 for specific regression weights and significance levels.

\section{$\underline{\text { Summary }}$}

This chapter began with an overview of the study presented in chapter three followed by the results of each model including descriptive statistics. The 
descriptive statistics presented normality problems that were addressed through $\log$ transformations. The descriptive statistics also provided insight on the dispersion of wealth in Oklahoma. The standard deviation value was very close to the mean for both capital outlay expenditures and net assessed valuation demonstrating a very wide range and explaining the normality issues.

The t-test confirmed the dispersions results found in the descriptive results. Rural communities were shown to have a higher mean on property values; however, this variable had very high standard deviation. Conversely, non-rural schools demonstrated the same pattern in capital outlay expenditures. Both measures were statistically significant, and these results are counter-intuitive. One would expect that higher mean net assessed valuation would result in higher mean capital outlay expenditure. Bond issue rates were similar for both rural and non-rural and not significant. Socio-economic status was shown to have the highest amount of influence on capital outlay spending and student achievement. This should not be a surprising result. 
Table 8 Regression Models for Achievement (DISTAPI)

\begin{tabular}{|c|c|c|c|c|c|}
\hline Predictors & $B$ & $S E B$ & $\beta$ & $R^{2}$ & $F$ \\
\hline \multicolumn{6}{|l|}{ Year 1 } \\
\hline Net assessed & 20.72 & 42.64 & .04 & .407 & 16.48 \\
\hline Bond passage & 87.79 & 64.76 & .10 & & \\
\hline MSA designation & 6.73 & 24.14 & .02 & & \\
\hline District SES & -391.88 & 52.75 & $-.61 * * *$ & & \\
\hline Capital outlay & 3.07 & 9.20 & .02 & & \\
\hline \multicolumn{6}{|l|}{ Year 2} \\
\hline Net assessed & 117.69 & 66.84 & .15 & .599 & 22.42 \\
\hline Bond passage & -81.64 & 83.28 & -.07 & & \\
\hline MSA designation & 47.90 & 32.48 & .12 & & \\
\hline District SES & -508.19 & 70.70 & $-.65^{* * * *}$ & & \\
\hline Capital outlay & 29.35 & 14.39 & $.17^{*}$ & & \\
\hline \multicolumn{6}{|l|}{ Year 3} \\
\hline Net assessed & 99.72 & 48.74 & $.18^{*}$ & .470 & 14.89 \\
\hline Bond passage & 28.28 & 94.88 & .02 & & \\
\hline MSA designation & 9.15 & 26.35 & .03 & & \\
\hline District SES & -467.30 & 68.67 & $-.61 * * *$ & & \\
\hline Capital outlay & -7.97 & 10.53 & -.06 & & \\
\hline \multicolumn{6}{|l|}{ Year 4} \\
\hline Net assessed & 10.07 & 44.50 & .02 & .370 & 11.28 \\
\hline Bond passage & 57.44 & 65.93 & .07 & & \\
\hline MSA designation & 3.50 & 24.40 & .01 & & \\
\hline District SES & -379.84 & 63.82 & $-.57 * * *$ & & \\
\hline Capital outlay & 5.87 & 11.89 & .04 & & \\
\hline \multicolumn{6}{|l|}{ Year 5} \\
\hline Net assessed & 53.53 & 36.83 & .12 & .465 & 16.70 \\
\hline Bond passage & -85.59 & 59.63 & -.11 & & \\
\hline MSA designation & 19.91 & 20.31 & .08 & & \\
\hline District SES & -447.59 & 56.27 & $-.67 * * *$ & & \\
\hline Capital outlay & -0.18 & 9.04 & -.00 & & \\
\hline
\end{tabular}

Note. Log transformed variables were used for COE and NAV. The constants for the models are as follows: Year $1=1065.18$, Year $2=802.69$, Year $3=892.64$, Year $4=1283.27$, Year $5=$ 1276.50. SES represents poverty not wealth. ${ }^{*} p<.05 . * * *<.001$. 
These results provide a comprehensive understanding of the capital outlay funding mechanisms in Oklahoma and how they interact to affect rural and non-rural schools. They also provide a base with which to improve the funding system in Oklahoma so that capital outlay dollars are being spent to improve the education for all students. The following chapter provides the findings, conclusions, and implications drawn from this analysis. 


\section{Chapter 5}

\section{Findings, Conclusions, and Recommendations}

Following a general overview of the study and a review of the research questions, this chapter uses the results provided in the previous chapter to determine directions for future considerations by policy makers and researchers. Conclusions are based on these findings and presented in an enumerated format followed by recomendations for future research and policy change. The summary details this chapter and the entire study.

The purpose of this study was to explore the relationships that exist among the mechanisms that drive capital outlay funding in Oklahoma. Also, the study was designed to demonstrate the impact that these mechanisms and capital outlay funding as a whole have on school performance. A review of the literature demonstrated the change in focus for equity from facilities to classroom resources and back to facilities over the last 35 years. Despite the arguments in court for more equity in facilities, little research has been conducted on capital outlay funding and student achievement. Oklahoma has a generally equitable general funding system, but provides no state support for capital outlay funding. All revenue for facility construction and maintenance comes from local property wealth. 
Capital outlay expenditures, local wealth, local support, socio-economic status, rurality, and district performance measures over a five year period were used as the six variables. These variables were then used to analyze these four research questions.

1. Is there a statistically significant difference in each of the following indicators of district capacity to meet capital outlay needs among Oklahoma districts according to Metropolitan Statistical Area classification?
a. Bond passage rates
b. Per pupil capital outlay expenditures
c. Net assessed valuation per pupil

2. Is there a statistically significant relationship between district socioeconomic status and the following indicators of local district ability to meet capital outlay needs in Oklahoma?
a. Bond passage rates
b. Per pupil capital outlay expenditures
c. Net assessed valuation per pupil

3. What is the predictive power of each of the following district characteristics on capital outlay expenditures per pupil in Oklahoma?

a. Bond passage rates 
b. MSA designation

c. District SES

4. Is there a statistically significant relationship between each of the following district characteristics and achievement among Oklahoma school districts?
a. Bond passage rates
b. MSA designation
c. District SES
d. Capital outlay expenditures per pupil

Descriptive statistics were used to examine general associations among the variables and determine appropriateness of the statistical models. Two variables - net assessed valuation and capital outlay expenditures - were determined to be outside acceptable normality ranges, and statistical methods were used to correct the variables.

\section{$\underline{\text { Findings }}$}

Both capital outlay expenditure and net assessed valuation demonstrated extreme positive skews, indicating fewer yet extreme values at the high end. Both variables also demonstrated high (nearly twice the mean) standard deviations. The most alarming finding in the descriptive statistics was the 
difference between the mean and maximum of capital outlay expenditures. The Mean ranged from $\$ 250.61$ in 2002 to $\$ 313.27$ in 2005 . However, the maximum capital outlay expenditure ranged from $\$ 4028.90$ in 2003 to $\$ 6768.90$ in 2001 , an average difference of $\$ 5299.87$ per pupil. During the five years studied, an average of $15 \%$ of school districts passed bond issues, representing an average of $80 \%$ approval of all bond issue questions over this same period. Because about $15 \%$ of districts passed bond issues each year, it may be assumed that over the five year period about half of the districts statewide were in some state of completion of a capital outlay project. It should be understood that some districts passed bond issues each year while others passed no bond issues at all. With half of the districts spending capital outlay on major building projects, it is shocking to see a $1200 \%$ difference in per pupil expenditure even if it is not on average. These data demonstrate the large range among capital outlay funding in Oklahoma.

During these five years, net assessed valuation (local property wealth) showed steady growth; however, capital outlay expenditures did not. More revenue should have been available during this time, but it was not utilized to build schools. Also, the standard deviation of net assessed valuation grew with each year of data. The maximum grew along with mean and standard deviation, but the minimum did not demonstrate the same growth. Net assessed valuation mean grew from $\$ 24,648.96$ in 2001 to $\$ 34,151.06$ in 2005 . Standard deviation 
grew from $\$ 27,329.17$ in 2001 to $\$ 54,493.24$ in 2005 . The maximum increased $\$ 423,536.00$ over the same five year period. Over the five year period analyzed, the property values generally increased, but the wealthy districts realized a much greater benefit in property values. The increase in local wealth at the high end was coupled with a large dispersion of values. The property poor districts did not experience nearly as much increase in property values as the property rich districts, and the benefit of increased property values was not uniform across the state. The range of these values was so extreme that the variables had to be $\log$ transformed before analysis.

The percentage of students participating in the free or reduced lunch program increased during the five years, and the standard deviation for that variable decreased. This finding indicates that poverty is increasing and becoming more common for all districts.

District academic performance index scores grew each year while the standard deviation for that variable was steady. Not all districts received a score for all years; if too few students participated, no scores were reported. Additionally, small districts may have had scores invalidated. The mean API scores increased $4 \%$ in 2004 and $6.5 \%$ in 2005 . These two years represent the low and high changes of the Mean over the five years studied. The overall increase in mean scores for the five years was $18 \%$. The federal No Child Left Behind law requires that districts make sustained incremental gains in API 
scores. Benchmarks have been established for every two years with a perfect 1500 a theoretical requirement in 2014 . While this study should not be used to make determinations on the validity of these scores and the related increase, these results do provide questions about the testing practices. This type of uniform increase with relatively stable standard deviations suggests that all Oklahoma schools are making a very similar amount of progress each year. Research question one compared rural and non-rural on each region's ability to meet capital outlay needs through analysis of local support for bond issues, capital outlay expenditures, and property wealth. By using t-tests, this model demonstrates if schools located in rural regions of Oklahoma and schools located in non-rural regions of Oklahoma differ in their ability to build or improve facilities. During the five years studied, local support was never significantly different between the two variables. However, important issues were shown in the data. The percentage of non-rural schools requesting bond funding from the community was twice the percentage of rural schools doing the same, yet rural schools have a higher net assessed valuation per pupil than nonrural schools. $30 \%$ of all non-rural schools requested bond issues in 2001 only $14 \%$ of rural schools did the same. During that same year, rural schools had local wealth $\$ 8000$ more per pupil than non-rural schools. It may be that rural school administrators are not taking advantage of bonding capacity. 
Administrators in rural communities understand the challenges of passing bond issues and may be less likely to request bond funding from local communities. This analysis may demonstrate a disconnect between net assessed valuation and individual property owners ability to support higher property taxes. The large family owned tracts of farmland often provide little income, yet non-rural communities support commercial and industrial districts. These tax bases along with denser populations spread the tax increases over more taxpayers.

Both capital outlay expenditure and net assessed valuation was significantly different for both classifications for all years. This finding demonstrates that rural and non-rural schools provide valid classifications for studying the capital outlay funding system in Oklahoma. The Mean for capital outlay expenditure in the non-rural setting was higher than in the rural setting for each year studied. Net assessed valuation was higher for rural settings over this same period. However, the standard deviation for rural NAV was almost twice as high as non-rural. This demonstrates a large range of values for the rural districts.

Research question two examined if there was a relationship between poverty level and a school district's ability to meet capital outlay needs. By analyzing the correlation among socio-economic status, local support for bond issues, capital outlay expenditures, and net assessed valuation, question two 
provided an understanding for the effect of poverty on capital outlay issues. Poverty level was not significantly related to local support for bond issues. Poverty level had a significant negative relationship to net assessed valuation and capital outlay expenditure. Families that struggle financially live in communities with limited property wealth. This results in fewer capital outlay dollars available to fund building projects. The relative wealth of a family does not determine their willingness to support bond issues, but it does determine their ability.

Research question three asked what funding mechanisms are responsible for capital outlay expenditure. The four variables - net assessed valuation, local support, rurality, and poverty - were analyzed to determine their individual and group influence on capital outlay expenditure. Local property values, poverty, local support, and location were significant as a group in three of the five years studied. Socio-economic status was a significant predictor of capital outlay expenditure each year except 2005. Rurality was significant in 2001 and 2004 with non-rural being a predictor of capital outlay expenditures. Questions two and three demonstrate that students living in poverty in Oklahoma are more likely to attend schools that spend less on facilities and maintenance. It may be determined that by spending less on facilities these districts are more likely to operate schools that are old, run-down, and environmentally substandard. Also, students living in non-rural communities may attend schools spending more on 
capital outlay projects; therefore, these students may be attending school in facilities that are more appropriate for a quality education.

Research question four was perhaps the most important question. It asks how the funding mechanisms affect a student's educational experience. Socioeconomic status was the variable the drove the overall significance for the model. Socio-economic status is the most significant variable in student achievement in this model. The overall model for each year studied explained from $37 \%$ to $60 \%$ of the variance in district API scores. Capital outlay expenditure in 2002 and net assessed valuation in 2003 were the only variables other than socio-economic status to be significant in any year. These variables showed a positive relationship. In 2002, as capital outlay expenditures increased so did district performance on the academic performance index. Although only significant in 2002, this type of relationship occurred in four of the five years. This model supports the common knowledge that personal wealth is a strong contributor to student achievement.

\section{$\underline{\text { Conclusions }}$}

1. The extreme positive skew of the net assessed valuation data and the growth of the maximum in net assessed valuation coupled with little or no growth in the minimum demonstrate that property values are 
increasing more quickly in the communities that already experience an advantage in net assessed valuation.

2. The uniform increase in API scores across the state of Oklahoma is suspect. The scores on district API for each year demonstrated high normality. While studying the roll normality plays in statistical analysis, Miceer ${ }^{82}$ found that criterion tests tended to be "extremely asymmetric" with at least one heavy tail. It should be considered unlikely that Oklahoma is experiencing such high uniform gains in standardized test scores.

3. Rural districts are pursuing bond issues at a much slower rate than nonrural districts. The reasons for this pattern are not shown in this study; however, the net effect may put rural school students at a disadvantage. The work of McColl and Malhoit ${ }^{83}$ that is cited in the review of literature may explain a portion of this finding. McColl and Mallhoit suggest that states have a building needs assessment to determine funding requirements. Rural school leaders may lack the appropriate skills to assess facility conditions or formulate long-range building plans.

\footnotetext{
${ }^{82}$ Miceeri, Theodore, The Unicorn, The Normal Curve, and Other Improbable Creatures. Psychological Bulletin. (1989).

${ }^{83}$ McColl, A. \& G.C. Malhoit, Policy Brief. Rural School Facilities: State Policies the Provide Students with an Environment to Promote Learning. Rural Trust Policy Brief Series on Rural Education. (2004).
} 
Similarly, districts may not have documentation and standards to present community members when explaining facility needs. A state-wide needs assessment based on standards would assist local education leaders in identifying and advertising the needs of school facilities.

4. Rural school districts are spending significantly fewer dollars on capital outlay than non-rural districts. Students attending school in rural schools will have a different experience than students attending school in nonrural schools. This study is not designed to interpret how the difference in capital outlay spending will impact each student; however, an intuitive conclusion should be that rural school students are experiencing the negative effects often associated with substandard buildings.

5. Local support for bond issues is generally the same regardless of household income or rurality. While rural and non-rural schools pursue bond issues at different rates, the level of support is about the same.

6. Socio-economic status has a significant impact on the amount of capital outlay expenditures by local school districts, and individual wealth is reflected in local property values that generate capital outlay dollars. Also, rural and non-rural designation is appropriate for studying and understanding school finance issues. Both of these conclusions support 
the views of Tyack and Cuban listed in the review of literature. ${ }^{84}$

Disparities in education are partially the result of place of residence and income.

7. With only three of five years showing a significant model for question three and low coefficients on each model, there are other variables influencing capital outlay expenditure but not being analyzed in this study.

8. Socio-economic status is a more significant variable in determining capital outlay spending than rurality. However, rural schools are spending less on capital outlay than non-rural schools. The introduction and review of literature of this study cited the Serrano case several times. At the core of this case was the idea that property wealth around the school should not determine the quality of education. The results of this study indicate a strong likelihood that this is happening in Oklahoma. Research questions two and three provide significant results identifying socio-economic status as the key variable in determining funding for the maintenance, upgrade, and new construction of school buildings.

${ }^{84}$ Tyack, D. \& L. Cuban, Tinkering Toward Utopia: A Century of Public School Reform. Cambridge, MA: Harvard University Press. (1995). 


\section{$\underline{\text { Recommendations }}$}

1. The Oklahoma State Department of Education must provide standards for school facilities. All school districts must have guidelines to assist in assessing current facilities and determining when to implement capital outlay projects. These guidelines should also assist local boards of education in determining the scope of the project. Theses standards should prohibit buildings from being "patched" when large scale upgrades are more appropriate.

2. Subsequent studies should examine why rural school districts do not pursue bond issues at the same rate as non-rural school districts. These studies should examine net assessed valuation by quartiles to better understand why this variable is so much higher for rural districts yet has a higher standard deviation. This study will demonstrate the relationship between property values and personal wealth of both the individual tax payer and the community. This study should attempt to determine if low API scores are the result of the social aspects of poverty or the low $\mathrm{COE}$ associated with districts experiencing high levels of poverty. This same study should include the affects of the supermajority vote on rural and non-rural districts. 
3. Subsequent studies should include case-studies of Oklahoma schools to determine how the physical environment affects student achievement. Precise descriptions of facilities should be compared to measures of student achievement.

4. Local property values must not be the only source for capital outlay dollars. This revenue source is directly connected to socio-economic status. Socio-economic status plays a significant role in most aspects of education including student achievement. It should no longer determine the condition of the physical school environment. More diverse revenue sources will create a more stable base for funding and reduce the burden on property owners.

\section{$\underline{\text { Summary }}$}

This study presented a detailed history of public school finance from the perspectives of equity, student achievement, and tax burden. It also provided an overview of the importance of rural communities in the United States. It was shown that there is a need for more literature in the field of capital outlay expenditures in public schools. By providing an analysis of five years of data from 540 Oklahoma school districts, this study supports an in-depth understanding of how funding mechanisms in Oklahoma influence capital outlay 
projects and affect student achievement. This analysis was used to generate specific conclusions, and the implications for further study were provided. Also, the implications for policy changes within the Oklahoma State Department of Education were given.

The results show that students living in low socio-economic households are attending schools where less is being spent on capital outlay than in districts supported by more affluent communities. There is also modest evidence that students living in rural communities are attending schools spending less on capital outlay. This study failed to demonstrate that capital outlay or the lack of has a significant impact on student achievement; however, socio-economic status has a very strong relationship with student achievement. As it is important for educators to maximize their influence on student achievement where possible, building condition must be considered as a viable subject for further research. While the financial indicators of capital outlay in this study do not significantly impact student achievement, it is important to consider two findings that where significant. Poor students attend school in districts where less is being spent on capital outlay and performance on achievement measures is lower in districts with high levels of poverty than in other districts. These findings show that the impact of capital outlay funding mechanisms in Oklahoma negatively affects poor students. 


\section{$\underline{\text { References }}$}

Addonizio, M.G., "From Fiscal Equity to Educational Adequacy: Lessons from Michigan," Journal of Education Finance 28 (Spring 2003), 457-484.

(Summer 2001): 585-608.

Alspaugh, John W., School Size as a Factor in Financing Small Rural Schools. Paper presented at the annual meeting of the American Educational Research Association. Montreal, Quebec, Canada. ERIC Document Reproduction Service No. ED 430745 (1994).

American School \& University. $29^{\text {th }}$ Annual Education Official Construction Report. [On-line]. Available: http://asumag.com/mag/university_strong_showing_2/index.html.

Berry, Michael A. Healthy School Environment and Enhanced Educational Performance: The Case of Charles Young Elementary School. . Washington DC: The Carpet and Rug institute (2002).

Bingler, S., B. M. Diamond, B. Hill, J. L Hoffman, C. B. Howley, B. K. Lawrence, S. Mitchell, D. Rudolph, \& E.Washor, Dollars \& Sense: The Cost Effectiveness of Small Schools. Washington DC: Rural School and Community Trust, Knowledge Works Foundation, and Concordia, Inc (2002).

Colemen, J.S., \& et al., Equality of Educational Opportunity (Washington D.C.: Office of Education, 1966).

Congressional Record - House (Oct. 8, 2003). [On-line]. Available: http://thomas.loc.gov/cgi-bin/query/D?r108:10:./temp/ r108zOKsXD

Crampton, F.E., "Financing Education in the Twenty-First Century: What State Legislative Trends of the 1990's Portend" Journal of Education Finance, 27 (Summer 2001), 479-500. 
Earthman, G.I., C.S. Cash, \& D. Van Berkum, A Statewide Study of Student Achievement and Behavior and School Building Condition. Paper presented at the Annual Meeting of the Council of Educational Facility Planners, International on September 19, 1995.

Education Commission of the States. Finance: Making Better Decisions About Funding School Facilities. Finance: Capital Construction. Denver, CO: Author. Retrieved August 9, 2005, from http://www.ecs.org/clearinghouse/13/23/1323.doc.

Fair School Finance Council of Oklahoma, Inc. v. State 1987 OK 114, 746 P.2d 1135

Flanigan, R.L., Setting the Bar Higher. Educational Vital Signs. Available: http://www.asbj.com/evs/04/fundingfacilities.html (2004).

Funk, Patricia E., \& Jon Bailey, Small Schools, Big Results: Nebraska High School Completion and Postsecondary Enrollment Rates by Size of School District. [on-line]. Available: http://www.cfra.org/Small_schools.htm. (1999)

Guthrie, J.W., \& R.A. Rothstein, “Enabling 'Adequacy' to Achieve Reality: Translating Adequacy into State School Finance Distribution Arrangements," Equity and Adequacy in Education Finance: Issues and Perspectives, Ladd, H.F., Rosemary C., \& Hansen, S. ed., (Washington DC: National Academy Press, 1999), 209-259.

Guthrie, J.W., \& R.A. Rothstein, “A New Millennium and A Likely New Era of Education Finance" Education Finance in the New Millennium AERA 2001 Yearbook. Chaikind, S, \& Wiliam, J.F. eds.

Haas, Toni, Balance Due: Increasing Financial Resources for Small Rural

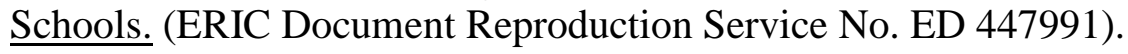
(2000). 
Hacsi, Timothy A., Children as Pawns: The Politics of Education Reform. Cambridge, MA: Harvard University Press (2002).

Harmon, Hobart L. Education Issues in Rural Schools of America. Paper presented at the Appalachian Rural Systemic Initiative Conference. (ERIC Document Reproduction Service No. ED 455987). (2001, May).

Hughes, Mary F. Financing in Rural School Districts: Variations among the States and the Case of Arkansas. In Improving Rural School Facilities: Design, Construction, Finance, and Public Support (pp. 21-39). (ERIC Document Reproduction Service No. ED 445857). (2000).

HVACMALL.com Energy Efficiency and School Construction Legislation face Uncertain Future. Sheet Metal \& Air Conditioning Contractors National Association. [On-line]. Available:

htttp//www.hvcmall.com/news/article_01067.htm. (2003).

Jimerson, Lorna, Still “A Reasonably Equal Share": Update on Educational Equity in Vermont: Year 2001-2002. Washington DC: Rural School and Community Trust. (2002).

Joyner, Amy, Funding Facilities A Billion - Dollar Building Boom. Education Vital Signs. [on-line]. Available: http://www.asbj.com/evs/04/fundingfacilities.html. (2004).

Lackney, Jeffery A. The Relationship between Environmental quality of school Facilities and Student Performance. Energy Smart Schools: Opportunities To Save Money, Save Energy and Improve Student Performance. A Congressional Briefing to the U.S. House of Representatives Committee on Science. [on-line]. Available: htttp://www.edi.msstate.edu/performance.html. (1997).

Ladd, H.F., R. Chalk, \& J.S. Hansen eds. Equity and Adequacy in Education Finance (Washington D.C.: National Academy Press 1999). 
Ladd, H.F.,\& J.S. Hansen eds. Making Money Matter: Financing America's Schools (Washington D.C.: National Academy Press 1999).Lawrence, Barbara Kent. Save a Penny, Lose a School: The Real Cost of Deferred Maintenance. Washington DC: The Rural School and Community Trust. (2003).

Lee, Jaekyung. Interstate Variations in Rural Student Achievement and Schooling Conditions. Washington DC (ERIC Document Reproduction Service No. ED 459037). (2001).

Maiden, Jeffrey, Funding School Infrastructure in Rural America. Saving America's School Infrastructure. (2003). 129-146.

Maiden, J. and R. Stearns. "Fiscal Equity Comparisons Between Current and Capital Education Expenditures and Between Rural and Nonrural Schools in Oklahoma," Journal of Education Finance 33 (2007): 147169.

Mead, Sara School Construction. Policy Report. Progressive Policy Institute. Washington, DC. (ERIC Document Reproduction Service No. ED 458785). Also available: http://www.pionline.org/ppi_ci.cfm?knlg. (2001).

McColl, Ann \& Gregory C. Malhoit, Rural School Facilities: State Policies that Provide Students with an Environment to Promote Learning. Washington DC: The Rural School and Community Trust. (2004).

McCraken, J.D., \& D.D. Peasley, Rural Ohio School Expenditure and student Achievement. Wooster, OH. Ohio Agricultural Research and Development Center. (ERIC Document Reproduction Service No. ED 409128). (1994).

Miceeri, Theodore, The Unicorn, The Normal Curve, and Other Improbable Creatures. Psychological Bulletin. 105, 156-166. (1989). 
Minorini, P.A., \& S.D. Sugarman, "School Finance litigation in the Name of Educational Equity" Equity and Adequacy in Education Finance: Issues and Perspectives, Helen F. Ladd, Rosemary Chalk, and Janet S. Hansen, eds. Washington, D.C.: National Academy Press (1999) 49.

Peevely, Gary, \& John R. Ray, The Relationship of Rurality and Education Accountability Outcomes. Paper presented at the Annual Meeting of the American Educational Research Association. Seattle, WA. (ERIC Document Reproduction Service No. ED 441985). (2001).

Rural Policy Matters. Smaller Schools Can Reduce Poverty's Power: Georgia Research Results Released. Retrieved from: http://www.ruraledu.org. (2000).

Smith, Mary L. Political Spectacle and the Fate of American Schools. New York: Routledge Falmer (2004).

Stiefel, L, P. Iatarola, N. Fruchter, \& R. Berne, The Effects of Size of Student Body on School Costs and Performance in New York City High Schools. New York, NY: New York University Institute for Education and Social Policy, Bruner Foundation, Inc., New York Community Trust, Robert Sterling Clark Foundation, Robin Hood Foundation. (ERIC Document Reproduction Service No. ED 420464). (1998).

Thompson, D.C., "The Impact of School Finance Litigation: A Long View" The Journal of Education Finance. 27 (Winter 2002) 133-172.

Thompson, D.C., and F.E. Crampton, "The Impact of School Finance Litigation: A Long View," Journal of Education Finance 27 (2002), 133-173.

Thorson, Gregory R., \& Maxwell, Nicholas J. Small Schools Under Siege: Evidence of Resource Inequality in Minnesota Public Schools. Minnesota State University, Mankato, Center for Rural Policy and 
Development. (ERIC Document Reproduction Service No. ED 468840). (2002).

Wyckoff, P.G., "Capitalization and the Incidence of School Aid" Journal of Education Finance 27 (Summer 2001), 585-608 